\title{
At-sea movement patterns and diving behavior of Peruvian boobies Sula variegata in northern Peru
}

\author{
Carlos B. Zavalaga ${ }^{1,6, *}$, Joanne N. Halls ${ }^{2}$, Gina P. Mori ${ }^{3}$, Scott A. Taylor ${ }^{4}$, \\ Giacomo Dell'Omo ${ }^{5}$ \\ ${ }^{1}$ Department of Biology and Marine Biology, ${ }^{2}$ Department of Geography and Geology, \\ University of North Carolina Wilmington, Wilmington, North Carolina 28403, USA \\ ${ }^{3}$ Calle Eduardo del Castillo 2543, Lima, Lima 1, Peru \\ ${ }^{4}$ Department of Biology, Queen's University, Kingston, Ontario K7L 2J3, Canada \\ ${ }^{5}$ Ornis Italica, Piazza Crati 15, 00199 Rome, Italy \\ ${ }^{6}$ Present address: Graduate School of Environmental Studies, Nagoya University, Sonoyoma House 105, \\ Sonoyama-cho 2-21-1, Chikusa-ku, Nagoya 464-0812, Japan
}

\begin{abstract}
GPS loggers and time-depth recorders were used to characterize the foraging behavior of the sexually dimorphic Peruvian booby Sula variegata on 2 islands in northern Peru. We evaluated whether (1) its foraging behavior differed from tropical boobies and temperate gannets (the Peruvian boobies feed in areas of enhanced productivity and high fish density), and (2) females and males exploited different foraging habitats as a consequence of size dimorphism. Birds foraged only during daylight hours, 1 to 3 times a day, in trips of short duration (median =1.8 h). Overall, $92 \%$ of the total foraging time was spent flying. They fed exclusively on anchovetas Engraulis ringens, which were captured in shallow dives (median $=2.5 \mathrm{~m}, \max =8.8 \mathrm{~m}$ ) with a dive median rate of 11 dives $^{-1}$ $\left(\max =37\right.$ dives $\left.\mathrm{h}^{-1}\right)$. The median foraging range was $25 \mathrm{~km}(\max =68 \mathrm{~km})$, whereas the median total distance traveled was $69 \mathrm{~km}(\max =179 \mathrm{~km})$. Foraging site fidelity was high, and the orientation of foraging flights in any given day was similar among birds that departed at the same time. There were no sex-specific differences in 13 of 15 foraging variables; however, females dived slightly deeper and spent a larger proportion of time sitting on the water. We speculate that (1) the foraging behavior of Peruvian boobies contrasts with that of their tropical and temperate relatives as a result of the proximity and predictability of food sources, elevated energetic demands of the brood (up to 4 chicks) and high prey encounter rate in the Peruvian upwelling system, and (2) the lack of spatial segregation between sexes may be related to the attraction of birds to feeding aggregations that are formed in the vicinity of the colonies. Once the foraging patches are localized, females dive deeper because of passive mechanisms associated with a heavier mass.
\end{abstract}

KEY WORDS: Anchoveta · Diving behavior · GIS - GPS tracking · Peruvian booby - Sexual size dimorphism $\cdot$ Spatial segregation $\cdot$ Sula variegata

Resale or republication not permitted without written consent of the publisher

\section{INTRODUCTION}

The foraging behavior of marine predators is strongly linked to oceanographic conditions, which in turn influence the distribution, abundance and predictability of prey (Hunt \& Schneider 1987, Daunt et al. 2006, Gende \& Sigler 2006, Biuw et al. 2007). One of the best known comparisons of this association is between seabirds from the oligotrophic waters of the tropics and those exploiting more productive waters of higher latitudes. For instance, foraging site fidelity is high in temperate and polar species compared to species in the tropics, because areas of enhanced marine productivity at meso- or larger scales (>100 km) are more predictable in space and time in polar and temperate regions than in tropical waters (Hyrenbach et al. 2002, Weimerskirch 2007). Although the at-sea distribution of seabirds may be closely tied to prey distri- 
bution, other behavioral, morphological or physiological constraints can also influence this association (Shaffer et al. 2001, Camphuysen et al. 2006). For instance, within the Sulidae (boobies and gannets), the maximum foraging distance of the tropical red-footed booby Sula sula and the masked booby S. dactylatra seems to be restricted by the fact that birds forage only during daylight (Weimerskirch et al. 2006, 2008). This strategy probably evolved to favor the encounter of multispecies feeding flocks catalyzed by tunas and dolphins that bring prey near the surface (Au \& Pitman 1986, Ballance et al. 1997, Jaquemet et al. 2004) and/or to reduce predation by sharks as birds do not have to sit on the water at night (Weimerskirch et al. 2008). Conversely, temperate gannets Morus spp. usually travel greater distances from their colonies because they can extend the duration of the feeding trip for several days by spending the night at sea (Hamer et al. 2001, Grémillet et al. 2004, Adams \& Navarro 2005). Sulids from low-latitude coastal upwelling systems may exhibit a foraging strategy different to those of their tropical and high-latitude relatives because areas of enhanced marine productivity are relatively close to their colonies (Duffy 1983a) and usually persist throughout the year (Bakun 1987).

One of the most productive coastal upwelling ecosystems in the world occurs within the boundaries of the Humboldt Current off the west coast of Peru and Chile (Chavez et al. 2008). The annual primary production in this region is estimated at 613 to $2285 \mathrm{~g} \mathrm{C}$ $\mathrm{m}^{-2}$ (Barber et al. 1985, Daneri et al. 2000), comparable to estimates from other eastern coastal upwelling systems (mean annual primary productivity $=976,479$ and $1213 \mathrm{~g} \mathrm{C} \mathrm{m}^{-2}$ for the Benguela, California and northwest Africa, respectively; Chavez \& Messié 2009). The food web is dominated by a single species, the anchoveta Engraulis ringens, which supports one of the world's largest single-species fisheries (Pauly et al. 2002) and a high diversity of marine life, including 12 endemic species of seabirds (Crawford et al. 2006). Low anchoveta availability during warm episodes linked to El Niño Southern Oscillation (ENSO) leads to drastic changes in the local marine community, usually reflected in low breeding success and high mortality rates of anchoveta predators (Arntz \& Fahrbach 1996). The Peruvian booby Sula variegata is recognized as one of the most abundant seabirds of the Humboldt Current System (Jahncke et al. 1998, Weichler et al. 2004), with a population size in Peru at the end of 1999 of approximately 1.5 million birds (Goya 2000). Peruvian boobies in northern central Chile feed mainly on anchoveta, mackerel Trachurus murphyi and king gar Scomberesox saurus that are captured in coastal areas relatively close to their colonies (Ludynia et al. 2009). In Peru, they feed almost exclusively on anchoveta
(Jahncke \& Zileri 1998, Tovar \& Guillén 1988, Jahncke \& Goya 2000) obtained by rapid, shallow plunge dives (Nelson 1978, Duffy 1987). The dependence of boobies on this prey is reflected by population crashes recorded during ENSO events (Duffy 1983b) and periods of overfishing (Jahncke et al. 2004). Thus, the space utilization and diving behavior of Peruvian boobies should reflect the distribution and abundance of anchoveta.

The Peruvian booby is a relatively small sulid (1200 to $1500 \mathrm{~g}$ ), with females $19 \%$ heavier than males (Zavalaga et al. 2009). In comparison to other Sula spp., the degree of sexual size dimorphism of Peruvian boobies is intermediate between the highly dimorphic blue-footed ( $S$. nebouxii) and brown ( $S$. leucogaster) boobies and the less dimorphic Nazca (S. granti), masked and red-footed boobies (Nelson 1978). Differences in body weight and size seem to explain the sex-specific foraging behavior observed in blue-footed and brown boobies, with larger females feeding farther from the colony and diving deeper than males (Zavalaga et al. 2007, Weimerskirch et al. 2009). Likewise, the smaller size and longer tail of male red-footed boobies confer them a higher agility that may result in sex-specific foraging niche segregation (Weimerskirch et al. 2006). Nevertheless, other studies have revealed that sexual size dimorphism in seabirds is most consistent with the sexual selection hypothesis via the agility of male displays (Catry et al. 1999, Serrano-Meneses \& Székely 2006) and that foraging segregation is not necessarily the result of size asymmetry between sexes (Lewis et al. 2002, Peck \& Congdon 2006, Welcker et al. 2009).

In the present study, we report the use of precision GPS logging technology in conjunction with timedepth recorders (TDRs) to study the at-sea movement patterns and diving behavior of Peruvian boobies from Isla Lobos de Tierra and Isla Lobos de Afuera. First, we evaluated the birds' foraging behavior in a rich upwelling region and compared it with what is known from other sulids. More specifically, we tested whether Peruvian boobies foraged closer to their colonies and more frequently than tropical boobies and temperate gannets. Second, we examined whether females and males exploited different foraging habitats as a consequence of size dimorphism.

\section{MATERIALS AND METHODS}

Study site. Peruvian boobies were studied on 2 islands in northern Peru: Lobos de Tierra (LT; 6 $24^{\prime} \mathrm{S}$, $80^{\circ} 51^{\prime} \mathrm{W}$ ) between 22 and 30 December 2006, and Lobos de Afuera (LA; $6^{\circ} 57^{\prime} \mathrm{S}, 80^{\circ} 41^{\prime} \mathrm{W}$ ) between 10 and 17 December 2007. A description of the topography and 
fauna of LT and LA is given by Zavalaga et al. (2007) and Figueroa \& Stucchi (2008), respectively. Briefly, LT is an inshore inland (area = $1426 \mathrm{ha}$ ) located $15 \mathrm{~km}$ from the continent, whereas LA includes 2 offshore islands (Independencia and Cachimbo, total area = 236 ha) located $61 \mathrm{~km}$ to the nearest point on the mainland and $65 \mathrm{~km}$ south of LT. Both islands lie on the continental shelf and within the boundaries of the cold waters of the Humboldt Current (Zavalaga et al. 2010). Peruvian boobies on both islands nested in several dense groups (ca. 2 nests $\mathrm{m}^{-2}$ ) of 100 to 3000 nests each. During the study period, the breeding population (estimated from direct counts) was 2000 to 2500 pairs on LT and 5500 to 6000 pairs on LA (Isla Independencia only). The majority of nests contained half-grown chicks $(75 \%$ of the body covered with downy feathers). Modal brood size of studied birds was 2 chicks on LT (range $=1$ to $4, \mathrm{~N}=$ 14 nests) and 3 on LA (range $=1$ to $4, \mathrm{~N}=37$ nests).

Remote sensing data of sea surface temperature (SST) and chlorophyll a ( $\mathrm{chl} \mathrm{a}$ ) concentration revealed that water masses around LT (within a circle with a radius equivalent to the Peruvian booby maximum foraging distance of $50.5 \mathrm{~km}$ recorded in the present study) and LA (radius of $67.1 \mathrm{~km}$ ) were warmer (mean $\pm \mathrm{SD}$, SST: $\mathrm{LT}=20.3 \pm 0.7^{\circ} \mathrm{C}, \mathrm{LA}=20.3 \pm 0.7^{\circ} \mathrm{C}$ ) and slightly more productive (mean $\pm \mathrm{SD}$, chl $\mathrm{a}: \mathrm{LT}=4.5 \pm 7.3 \mathrm{mg}$ $\mathrm{m}^{-3}, \mathrm{LA}=2.9 \pm 3.2 \mathrm{mg} \mathrm{m}^{-3}$ ) in December 2006 than in December 2007 (mean $\pm \mathrm{SD}, \mathrm{SST}$ : $\mathrm{LT}=18.5^{\circ} \mathrm{C} \pm 0.8$, $\mathrm{LA}=18.5 \pm 0.9^{\circ} \mathrm{C}$; mean $\pm \mathrm{SD}$, chl $a: \mathrm{LT}=2.9 \pm 7.4 \mathrm{mg}$ $\mathrm{m}^{-3}, \mathrm{LA}=1.9 \pm 4.3 \mathrm{mg} \mathrm{m}^{-3}$ ) (Zavalaga et al. 2010).

Data-loggers. The movement patterns of Peruvian boobies were determined by using 2 types of GPS data-loggers equipped with an integrated antenna, a rechargeable battery and $8 \mathrm{Mb}$ flash memory (TechnoSmArt). The GiPSy-1 unit ( $33 \mathrm{~g}, 5 \times 3 \times 1 \mathrm{~cm}$ ) was set to take 1 position fix every $10 \mathrm{~s}$ for approximately $48 \mathrm{~h}$. The GiPSy- 2 unit $(14 \mathrm{~g}, 4.5 \times 2.2 \times 0.7 \mathrm{~cm})$ had a time interval between fixes set at $1 \mathrm{~s}$ for approximately $24 \mathrm{~h}$. At first, the GPS loggers were set to record data at $10 \mathrm{~s}$ intervals because the duration of feeding trips were unknown. We then changed the interval to $1 \mathrm{~s}$ because the battery lifespan was long enough to record the entire daily activity of the birds, which included more than one feeding trip per deployment. The accuracy of both loggers was $<10 \mathrm{~m}$ in $>95 \%$ of location fixes. Overall, two-thirds of birds were instrumented with the GiPSy-2; all other birds were equipped with the GiPSy-1. The loggers were protected in 2 heat-sealed waterproof polyethylene bags $(1 \mathrm{~g})$. After logger retrieval, the data were downloaded to a laptop computer using the dedicated GiPSy software (TechnoSmArt, www.technosmart.eu).

Diving behavior was recorded with bullet-shaped TDRs (5 g, $1.1 \times 3.2 \mathrm{~cm}$, Lotek LTD1110) set to collect data every $1 \mathrm{~s}$ for approximately $18 \mathrm{~h}$. The pressure sensor recorded depths with an accuracy of $\pm 0.3 \mathrm{~m}$ (depth range $=0$ to $30 \mathrm{~m}$ ). Data were downloaded using Tag Talk 1100 software (Lotek, www.lotek.com).

Bird capture. A total of 14 and 35 known-sex Peruvian boobies raising medium-sized chicks were captured for logger deployment between 05:30 and 07:00 h at LT and LA, respectively. Only 1 member of the pair was equipped and the sex of birds was determined by DNA analysis (Zavalaga et al. 2009). Birds were randomly selected from the second or third most external row of nests from 2 neighboring breeding groups (ca. 100 nests each) at LT and 1 breeding group at LA (ca. 3000 nests). Birds were removed from their nests using a $3 \mathrm{~m}$ hooked pole placed gently around their necks. The GPS data-loggers were wrapped around 4 central tail feathers using waterproof Tesa ${ }^{\circledR}$ tape. The TDRs were attached to a numbered metal band with 3 small plastic cable ties. Attachment of the loggers was completed in $<5 \mathrm{~min}$, and birds were released near their nests. Twelve birds at LT and 24 birds at LA were equipped with a GPS logger in conjunction with a TDR in order to identify locations where foraging occurred; the rest of the birds carried a GPS logger only. The TDRs and their accessories (band, tape and cable ties) added an additional weight of $16 \mathrm{~g}$ to the GPS loggers. The range of body weight recorded from all tagged birds was 1200 to $1675 \mathrm{~g}$; therefore, the GiPSy-2 and GiPSy-1 loggers accounted for a maximum 1.8 and $4.2 \%$ of the bird's body weight (mode $=$ $2 \%$ ), respectively, below the $5 \%$ limit recommended by the Ornithological Council Guidelines (www.nmnh. si.edu/BIRDNET/GuideToUse). The tagged boobies were marked with a short-lasting dye (rhodamine B) on the chest and head for easy sighting of birds in the colony. Boobies were recaptured 12 to $48 \mathrm{~h}$ later (82\% of birds recaptured between 10 and $14 \mathrm{~h}$ ) to retrieve the devices, weighed with a spring Pesola scale to the nearest $25 \mathrm{~g}$ and induced to regurgitate by holding them upside down and pressing gently on their belly until all stomach contents were regurgitated. The identification and number of prey was assessed on site because most prey items were undigested.

Handling of data and analyses. TDRs: The number, time, maximum depth, duration and profile of dives were calculated for each trip using Multitrace MT-Dive software (Jensen Software Systems). All dives with depths $<0.5 \mathrm{~m}$ were excluded because they might have been due to movements when the birds were sitting on the sea surface. Dives of Peruvian boobies were usually short and shallow (see 'Results') in relation to the sampling interval of $1 \mathrm{~s}$, leading to possible errors in the estimations of dive parameters. To improve the accuracy of the calculations, an additional point was inserted between 2 recorded consecutive points by using the interpolation option in MT-Dive. 
GPS data-loggers: The spatial data were mapped and analyzed using ArcGIS 9.2 (ESRI). The position fixes were projected to the Universal Transverse Mercator (Zone 5S) coordinate system for all spatial analysis, which included timing of foraging trips, flight speed, sinuosity index, trip length, at-sea activities and movement patterns. The ArcGIS extensions Hawth's Analysis Tools (www.spatialecology.com/htools) and Xtools Pro 5.2 (www.xtoolspro.com) were also applied for estimations of bearings, distances and areas.

The majority of birds landed on their nests after foraging, but a few landed away from the colony and returned to their nests several hours after landing. Using the nest as a central place for foraging would overestimate the duration of some trips; thus the duration of the foraging excursion was defined as the interval between the departure time from the nest to the landing time on the island. Departure and return times for each trip were identified by visual inspection of all tracks. Once the departure and arrival times were established, all positional fixes on land were excluded for subsequent analysis.

Instantaneous speeds were calculated from the distance and time elapsed between 2 consecutive position fixes in a foraging track. However, an inspection of the frequency distribution of speed revealed a clear threshold value of $10 \mathrm{~km} \mathrm{~h}^{-1}$ (Fig. 1), with lower speeds related to birds resting on the sea surface or diving and higher speeds related to flying birds. A similar bimodal distribution of speed has been found in other species of sulids (Grémillet et al. 2004, Weimerskirch et al. 2005a). Thus for the calculations and analysis of flight speeds we used values $>10 \mathrm{~km} \mathrm{~h}^{-1}$.

Path sinuosity was defined as the ratio of the total distance traveled in 1 min intervals to the straight line distance in that interval (every 60th fix for GiPSy 2 and

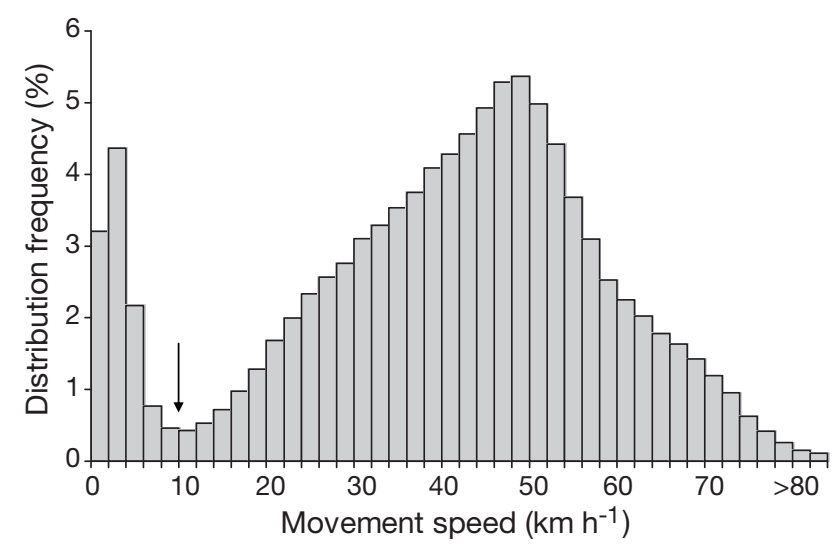

Fig. 1. Sula variegata. Distribution frequency of instantaneous movement speeds of birds from Lobos de Tierra and Lobos de Afuera ( $\mathrm{N}=299944$ fixes). Speeds were derived from all GPS fixes outside the breeding colony. The arrow indicates the cut-off value of $10 \mathrm{~km} \mathrm{~h}^{-1}$ every 6th fix for GiPSy-1). A sinuosity index close to 1 indicates high path linearity. To examine the linearity of the tracks at different sections of the foraging excursions, the average sinuosity index was calculated in 3 phases of the trip: outbound commute (from departure of the nest to the location of the first dive); middle (from the first to the last dive); and inbound commute (from the last dive to landing on the island).

The proportion of time spent flying in relation to the total duration of the feeding trip was estimated from the cumulative time of all data points with speeds $>10 \mathrm{~km} \mathrm{~h}^{-1}$. Consequently, the proportion of time spent on water (sitting or diving) was estimated from data points with speeds $<10 \mathrm{~km} \mathrm{~h}^{-1}$. The number of dives and dive duration was determined from the TDRs; therefore, it was possible to separate the time interval for sitting on the sea surface from the total time spent diving. Thus at-sea activities were categorized into flying, sitting on the sea surface and diving.

Individual tracks were reduced to 4 main components: (1) the clockwise angle between the nest and outmost foraging point (this angle was significantly correlated with the bearing to the location of the first dive [circular correlation, $\mathrm{r}=0.83, \mathrm{p}<0.05, \mathrm{~N}=50$ ], confirming that the bearing to the farthest point in the route was a good indicator of foraging direction); (2) the maximum foraging range, defined as the straight line distance between the nest and the farthest position fix in the route; (3) the cumulative distance travelled during the foraging flight; and (4) the nearest distance of the foraging track to the mainland. To determine whether Peruvian boobies dived continuously along the foraging path or fed at specific areas, a standardized index of dive locations was calculated in relation to the point of the maximum foraging range as follows:

$$
\overrightarrow{S D L}_{i j}=\left[\left(\vec{D}_{\max } j-\vec{D}_{\text {dive } j}\right) / \vec{D}_{\max } j\right]
$$

where $\overrightarrow{S D L}_{i j}$ is the standardized distance of the ith dive in a $j$ th foraging trip, $\vec{D} \max j$ is the maximum foraging range of the trip $j$ and $\vec{D}_{\text {dive }} j$ is the distance of the dive location $i$ from the nest. A value close to 1 indicated that dives occurred close to the maximum foraging range, whereas a value close to 0 indicated that dive locations were close to the island. If birds dived continuously, then we predicted a uniform frequency distribution of distances. Conversely, if boobies fed at specific areas before returning to the island, then the distribution would be skewed, with the majority of dives located around the farthest point in the route.

GPS data-loggers with TDRs: The TDRs were synchronized with the GPS loggers on the island to the nearest $1 \mathrm{~s}$ using the satellite time read from a conventional handheld GPS. Thus all dives were georeferenced and their locations used to identify foraging areas. The extent of the feeding areas was assessed 
using fixed kernel density estimation. This procedure not only tempers the effects of spatial autocorrelation of multiple dive position fixes from an individual, but it gives a more accurate estimation of the foraging areas than the minimum convex polygon calculated from peripheral data points (Wood et al. 2000). The kernel analysis estimated a $95 \%$ contour probability polygon from the pooled dive position fixes of females and males at each island. The bandwidth or search radius employed for the calculation of the $95 \%$ contour polygons was determined with the least square cross validation algorithm (LSCV, Seaman \& Powell 1996) using the Animal Movement Analysis extension (Hooge \& Eichenlaub 1997) in ArcView 3.3 (ESRI). The contour polygons around LT intersected land masses because the majority of dives were located in waters close to the mainland. Thus, for calculations of foraging areas, the intersected polygons on land were removed from the analysis.

Statistical analysis. Data were log-transformed before conducting statistical tests as most of the variables were not normally distributed. After transformation, data were tested for normality and homogeneity of variance using Shapiro-Wilk's and Levene's tests, respectively. The data set compiled for each bird included multiple sequential data values within a trip and usually more than one trip during each deployment, and therefore, the data values cannot be considered independent. To circumvent data autocorrelation at the bird level, general mixed linear models were applied with restricted maximum likelihood estimations (REML) for comparisons of foraging variables of categorical data (females vs. males, LT vs. LA), covariates (dive depth and maximum foraging distance) and their respective interactions. In this model, sex and island were defined as fixed factors, whereas bird identity was categorized as a random factor. If variances were not homogeneous or the distribution of data was not normal, then the non-parametric Kolmogorov-Smirnov (K-S) test was used for comparisons of distributions, and the Mann-Whitney $U$-test was used to compare the median of 2 unmatched samples with a low number of replicates. Logistic regression analysis was selected for data with a binary response (e.g. number of trips per day, 1 trip $=1,>1$ trip =0).

Angular data were examined with circular statistical tests (Batschelet 1981, Zar 1999). More specifically, the mean directional vector (r) was used to measure bearing dispersion, with $\mathbf{r}$ values close to 1 indicating that headings were highly concentrated to a specific location. Flight orientation was analyzed to the trip level because an average bearing for birds with multiple trips did not necessarily reflect the boobies' actual orientation (Zavalaga et al. 2008). To evaluate the difference in the mean bearing between sexes and islands, we used Watson's $U^{2}$ test. The Watson-Williams pairwise F-test was selected to examine the directional persistence of individuals across 2 subsequent trips. To examine whether birds were attracted by their congeners to feed in the same areas, we calculated the angular deviations of 4 to 7 foraging tracks from different birds of both sexes that departed approximately at the same time of the day (within a $1 \mathrm{~h}$ interval). The angular deviations from their respective means were then compared among 6 consecutive days using the Kruskal-Wallis test modified for circular data.

SAS was used for all statistical tests of linear variables (SAS Institute). Circular statistical analyses were performed using Oriana 2 software (Kovac Computing Service). Means are expressed \pm 1 SD unless otherwise indicated, and differences were deemed to be significant at $\mathrm{p}<0.05$.

\section{RESULTS}

All birds were recaptured in their nests 0.5 to $2 \mathrm{~d}$ after tag attachment. None of the GPS loggers were lost, but 4 failed to record data because water entered the bags. All other tags recorded data and as a result we obtained data from: (1) 33 birds equipped with GPS in conjunction with TDRs, (2) 3 birds carrying only TDRs and (3) 12 birds instrumented only with GPS loggers.

\section{Timing of departures and duration of feeding trips}

Departures from the colony on both islands occurred at any time from sunrise (06:00 h local time) to $2 \mathrm{~h}$ before sunset (19:00 h; Fig. 2). Most of the birds departed between 09:00 and10:00 h, and second and third trips began between 14:00 and 17:00 h. There were no differences in the time of departure between sexes (K-S, $D=0.16, \mathrm{p}=0.76)$ or between islands $(D=0.13, \mathrm{p}=$ 0.81 ). The bimodal distribution of the departure time was the result of birds making single or multiple trips in a day (51\% of birds made double, $44 \%$ single and $5 \%$ triple trips, $\mathrm{N}=43$ trips, Fig. 2). The number of trips in a day was similar between sexes and islands (Table 1). Birds that departed before noon had greater chances of making multiple trips per day (logistic regression, odd ratio $=1.93$, Wald $-\chi^{2}=6.59, \mathrm{p}=0.01$ ). Peruvian boobies never spent the night at sea, and always returned to the island before nightfall. From a sample of 11 birds at LT that carried GPS loggers for $>24$ h, $64 \%$ attended their nests overnight, whereas the rest spent the night on the island, but 0.1 to $5.5 \mathrm{~km}$ from the nest.

Trip length ranged from 0.4 to $5 \mathrm{~h}$ (median $=1.86 \mathrm{~h}$, $\mathrm{N}=43$ trips) and were significantly longer in birds 
Table 1. Sula variegata. Sex-specific differences in the foraging variables of Peruvian boobies breeding at Isla Lobos de Tierra in 2006 and Isla Lobos de Afuera in 2007. Descriptive statistics are expressed as means \pm 1 SD, with the range in parentheses and number of birds in italics. U/V dive ratio: ratio of the number of U-shaped to V-shaped dives. Superscripted letter in first columns of main effect statistics indicates statistical test $\left({ }^{\mathrm{a}}\right.$ : logistic regression ${ }_{i}{ }^{\mathrm{b}}$ : restricted maximum likelihood [REML] general mixed model $_{i}{ }^{\text {: }}$ chi-square), and applies to all test-statistics in the same row

\begin{tabular}{|c|c|c|c|c|c|c|c|}
\hline \multirow[t]{2}{*}{ Variable } & \multicolumn{2}{|c|}{ Isla Lobos de Tierra (2006) } & \multicolumn{2}{|c|}{ Isla Lobos de Afuera (2007) } & \multicolumn{3}{|c|}{ Main effect statistics } \\
\hline & Females & Males & Females & Males & Sex & Location & Sex $\times$ Location \\
\hline $\begin{array}{l}\text { Number of trips } \\
\text { per day }\end{array}$ & $\begin{array}{c}1.6 \pm 0.55 \\
(1-2) \\
5\end{array}$ & $\begin{array}{c}1.5 \pm 0.53 \\
(1-2) \\
8\end{array}$ & $\begin{array}{c}1.72 \pm 0.67 \\
(1-3) \\
18\end{array}$ & $\begin{array}{c}1.46 \pm 0.51 \\
(1-2) \\
13\end{array}$ & $\begin{aligned} \chi^{2} & =0.54^{\mathrm{a}} \\
\mathrm{p} & =0.46\end{aligned}$ & $\begin{aligned} \chi^{2} & =0.006 \\
p & =0.93\end{aligned}$ & $\begin{array}{c}\chi^{2}=0.02 \\
p=0.88\end{array}$ \\
\hline $\begin{array}{l}\text { Trip length } \\
\text { (h) }\end{array}$ & $\begin{array}{c}3.36 \pm 0.55 \\
(2.56-4.27) \\
8\end{array}$ & $\begin{array}{c}2.46 \pm 0.65 \\
(1.54-3.45) \\
10\end{array}$ & $\begin{array}{c}1.61 \pm 1.05 \\
(0.38-4.92) \\
32\end{array}$ & $\begin{array}{c}1.88 \pm 0.83 \\
(0.69-4.03) \\
21\end{array}$ & $\begin{array}{c}F_{1,41}=1.51^{b} \\
p=0.226\end{array}$ & $\begin{array}{c}F_{1,41}=17.5 \\
\mathrm{p}<0.001\end{array}$ & $\begin{array}{c}F_{1,41}=3.80 \\
p=0.06\end{array}$ \\
\hline $\begin{array}{l}\text { Dive depth } \\
\text { (m) }\end{array}$ & $\begin{array}{c}2.79 \pm 1.46 \\
(0.56-7.51) \\
3\end{array}$ & $\begin{array}{c}2.63 \pm 1.07 \\
(0.57-5.37) \\
9\end{array}$ & $\begin{array}{c}2.64 \pm 1.10 \\
(0.59-8.81) \\
15\end{array}$ & $\begin{array}{c}2.21 \pm 0.96 \\
(0.56-5.20) \\
9\end{array}$ & $\begin{array}{c}F_{1,32}=3.81^{b} \\
\mathrm{p}=0.06\end{array}$ & $\begin{array}{c}F_{1,32}=3.38 \\
\mathrm{p}=0.08\end{array}$ & $\begin{array}{c}F_{1,32}=0.63 \\
\mathrm{p}=0.43\end{array}$ \\
\hline $\begin{array}{l}\text { Maximum dive } \\
\text { depth }(\mathrm{m})\end{array}$ & $\begin{array}{c}6.33 \pm 1.32 \\
(4.91-7.51) \\
3\end{array}$ & $\begin{array}{c}4.60 \pm 0.67 \\
(3.24-5.37) \\
9\end{array}$ & $\begin{array}{c}5.00 \pm 1.33 \\
(3.72-8.81) \\
15\end{array}$ & $\begin{array}{c}3.84 \pm 0.98 \\
(2.53-5.20) \\
9\end{array}$ & $\begin{array}{c}F_{1,32}=10.9^{b} \\
p=0.002\end{array}$ & $\begin{array}{c}F_{1,32}=5.71 \\
\mathrm{p}=0.023\end{array}$ & $\begin{array}{c}F_{1,32}=0.426 \\
\mathrm{p}=0.52\end{array}$ \\
\hline $\begin{array}{l}\text { Dive duration } \\
\text { (s) }\end{array}$ & $\begin{array}{c}4.08 \pm 1.36 \\
(2-16.02) \\
3\end{array}$ & $\begin{array}{c}4.28 \pm 1.43 \\
(2-19) \\
9\end{array}$ & $\begin{array}{c}4.65 \pm 2.08 \\
(2-19.72) \\
15\end{array}$ & $\begin{array}{c}4.12 \pm 1.44 \\
(2-10) \\
9\end{array}$ & $\begin{array}{c}F_{1,32}=0.15^{b} \\
p=0.69\end{array}$ & $\begin{array}{c}F_{1,32}=0.01 \\
\mathrm{p}=0.97\end{array}$ & $\begin{array}{c}F_{1,32}=1.51 \\
\mathrm{p}=0.22\end{array}$ \\
\hline $\begin{array}{l}\text { U/V dive } \\
\text { ratio }\end{array}$ & $\begin{array}{c}0.055 \\
3\end{array}$ & $\begin{array}{c}0.08 \\
9\end{array}$ & $\begin{array}{c}0.088 \\
15\end{array}$ & $\begin{array}{c}0.151 \\
9\end{array}$ & $\begin{array}{l}\chi^{2}=2.11^{\mathrm{c}} \\
\mathrm{p}=0.147\end{array}$ & $\begin{array}{c}\chi^{2}=4.57 \\
p=0.03\end{array}$ & \\
\hline $\begin{array}{l}\text { Number of } \\
\text { dives per trip }\end{array}$ & $\begin{array}{c}53 \pm 13.47 \\
(31-68) \\
5\end{array}$ & $\begin{array}{c}39.3 \pm 13.9 \\
(19-63) \\
13\end{array}$ & $\begin{array}{c}19.26 \pm 9.94 \\
(5-43) \\
23\end{array}$ & $\begin{array}{c}18.69 \pm 7.61 \\
(9-39) \\
13\end{array}$ & $\begin{array}{c}F_{1,32}=3.54^{\mathrm{b}} \\
\mathrm{p}=0.07\end{array}$ & $\begin{array}{c}F_{1,32}=48.3 \\
\mathrm{p}<0.001\end{array}$ & $\begin{array}{c}F_{1,32}=2.48 \\
p=0.12\end{array}$ \\
\hline $\begin{array}{l}\text { Total dive rate } \\
\left(\text { dives } \mathrm{h}^{-1} \text { ) }\right.\end{array}$ & $\begin{array}{c}15.15 \pm 3.53 \\
(9.74-19.29) \\
5\end{array}$ & $\begin{array}{c}15.78 \pm 5.18 \\
(6.78-25.17) \\
13\end{array}$ & $\begin{array}{c}14.19 \pm 8.87 \\
(3.11-37.45) \\
23\end{array}$ & $\begin{array}{c}10.44 \pm 5.33 \\
(3.61-22.76) \\
13\end{array}$ & $\begin{array}{c}F_{1,32}=0.36^{b} \\
p=0.55\end{array}$ & $\begin{array}{c}F_{1,32}=1.48 \\
\mathrm{p}=0.23\end{array}$ & $\begin{array}{c}F_{1,32}=0.50 \\
\mathrm{p}=0.48\end{array}$ \\
\hline $\begin{array}{l}\text { Foraging dive } \\
\text { rate }\left(\text { dives } \mathrm{h}^{-1}\right)\end{array}$ & $\begin{array}{c}22.97 \pm 4.61 \\
(18.47-29.8) \\
5\end{array}$ & $\begin{array}{c}28.17 \pm 7.23 \\
(16.67-42.4) \\
13\end{array}$ & $\begin{array}{c}35.57 \pm 18.3 \\
(8.39-66.19) \\
22\end{array}$ & $\begin{array}{c}30.71 \pm 14.3 \\
(11.21-55.7) \\
13\end{array}$ & $\begin{array}{c}F_{1,32}=0.10^{b} \\
p=0.75\end{array}$ & $\begin{array}{c}F_{1,32}=2.23 \\
\mathrm{p}=0.15\end{array}$ & $\begin{array}{c}F_{1,32}=1.24 \\
\mathrm{p}=0.27\end{array}$ \\
\hline $\begin{array}{l}\text { Proportion of } \\
\text { time flying } \\
(\%)\end{array}$ & $\begin{array}{c}81 \pm 9 \\
(73-95) \\
5\end{array}$ & $\begin{array}{c}90 \pm 6 \\
(78-98) \\
10\end{array}$ & $\begin{array}{c}94 \pm 6 \\
(79-99) \\
23\end{array}$ & $\begin{array}{c}94 \pm 8 \\
(68-99) \\
12\end{array}$ & $\begin{array}{c}F_{1,29}=2.87^{\mathrm{b}} \\
\mathrm{p}=0.101\end{array}$ & $\begin{array}{c}F_{1,29}=11.8 \\
\mathrm{p}=0.002\end{array}$ & $\begin{array}{c}F_{1,29}=3.52 \\
\mathrm{p}=0.071\end{array}$ \\
\hline $\begin{array}{l}\text { Proportion of } \\
\text { time sitting on } \\
\text { the water }(\%)\end{array}$ & $\begin{array}{c}15 \pm 9 \\
(3-25) \\
6\end{array}$ & $\begin{array}{c}8 \pm 6 \\
(1-20) \\
10\end{array}$ & $\begin{array}{c}4 \pm 6 \\
(0-20) \\
32\end{array}$ & $\begin{array}{c}4 \pm 7 \\
(1-31) \\
21\end{array}$ & $\begin{array}{c}F_{1,41}=3.22^{\mathrm{b}} \\
\mathrm{p}=0.08\end{array}$ & $\begin{array}{c}F_{1,41}=13.3 \\
\mathrm{p}<0.001\end{array}$ & $\begin{array}{c}F_{1,41}=2.96 \\
\mathrm{p}=0.093\end{array}$ \\
\hline $\begin{array}{l}\text { Flight speed } \\
\left(\mathrm{km} \mathrm{h}^{-1}\right)\end{array}$ & $\begin{array}{c}39.3 \pm 3.5 \\
(10-139.5) \\
8\end{array}$ & $\begin{array}{c}40.9 \pm 2.6 \\
(10-111.3) \\
10\end{array}$ & $\begin{array}{c}44.8 \pm 3.3 \\
(10-128.8) \\
32\end{array}$ & $\begin{array}{c}45.7 \pm 2.9 \\
(10-90.2) \\
21\end{array}$ & $\begin{array}{c}F_{1,41}=1.23^{b} \\
p=0.27\end{array}$ & $\begin{array}{c}F_{1,41}=26.3 \\
\mathrm{p}<0.0001\end{array}$ & $\begin{array}{c}F_{1,41}=0.20 \\
\mathrm{p}=0.66\end{array}$ \\
\hline $\begin{array}{l}\text { Sinuosity } \\
\text { index }\end{array}$ & $\begin{array}{c}1.69 \pm 1.35 \\
(1.02-15.73) \\
4\end{array}$ & $\begin{array}{c}1.66 \pm 1.26 \\
(1.01-15.65) \\
7\end{array}$ & $\begin{array}{c}1.59 \pm 1.43 \\
(1-16.64) \\
19\end{array}$ & $\begin{array}{c}1.48 \pm 1.16 \\
(1.01-15.7) \\
14\end{array}$ & $\begin{array}{c}F_{1,41}=0.74^{\mathrm{b}} \\
\mathrm{p}=0.394\end{array}$ & $\begin{array}{c}F_{1,41}=0.92 \\
\mathrm{p}=0.344\end{array}$ & $\begin{array}{c}F_{1,41}=0.84 \\
\mathrm{p}=0.364\end{array}$ \\
\hline $\begin{array}{l}\text { Maximum } \\
\text { foraging range } \\
(\mathrm{km})\end{array}$ & $\begin{array}{c}31.1 \pm 12 \\
(14.3-50.5) \\
8\end{array}$ & $\begin{array}{c}29.8 \pm 12.1 \\
(16.4-48.4) \\
10\end{array}$ & $\begin{array}{c}23.9 \pm 17.7 \\
(4.5-67.9) \\
32\end{array}$ & $\begin{array}{c}29.3 \pm 14.5 \\
(9.9-58.6) \\
21\end{array}$ & $\begin{array}{c}F_{1,41}=0.04^{\mathrm{b}} \\
\mathrm{p}=0.84\end{array}$ & $\begin{array}{c}F_{1,41}=0.74 \\
\mathrm{p}=0.39\end{array}$ & $\begin{array}{c}F_{1,41}=0.30 \\
\mathrm{p}=0.58\end{array}$ \\
\hline $\begin{array}{l}\text { Total path } \\
\text { distance } \\
(\mathrm{km})\end{array}$ & $\begin{array}{c}106.9 \pm 19.2 \\
(72.6-126.9) \\
8\end{array}$ & $\begin{array}{c}89.7 \pm 24.1 \\
(58-124.7) \\
10\end{array}$ & $\begin{array}{c}65.6 \pm 44.3 \\
(14.9-178.7) \\
32\end{array}$ & $\begin{array}{c}76.6 \pm 36.4 \\
(22.8-175) \\
21\end{array}$ & $\begin{array}{c}F_{1,41}=0.21^{b} \\
\mathrm{p}=0.65\end{array}$ & $\begin{array}{c}F_{1,41}=5.35 \\
\mathrm{p}=0.026\end{array}$ & $\begin{array}{c}F_{1,41}=1.09 \\
\mathrm{p}=0.30\end{array}$ \\
\hline $\begin{array}{l}\text { Dive location } \\
\text { in relation to } \\
\text { colony }(\mathrm{km})\end{array}$ & $\begin{array}{c}24.81 \pm 8.84 \\
(8.31-50.5) \\
3\end{array}$ & $\begin{array}{c}25.61 \pm 10.6 \\
(1.13-48.1) \\
7\end{array}$ & $\begin{array}{c}23.05 \pm 15.5 \\
(4.46-67.16) \\
18\end{array}$ & $\begin{array}{c}27.89 \pm 15.5 \\
(0.98-58.6) \\
8\end{array}$ & $\begin{array}{c}F_{1,29}=0.05^{b} \\
p=0.82\end{array}$ & $\begin{array}{c}F_{1,29}=0.02 \\
\mathrm{p}=0.88\end{array}$ & $\begin{array}{c}F_{1,29}=0.13 \\
\mathrm{p}=0.72\end{array}$ \\
\hline
\end{tabular}




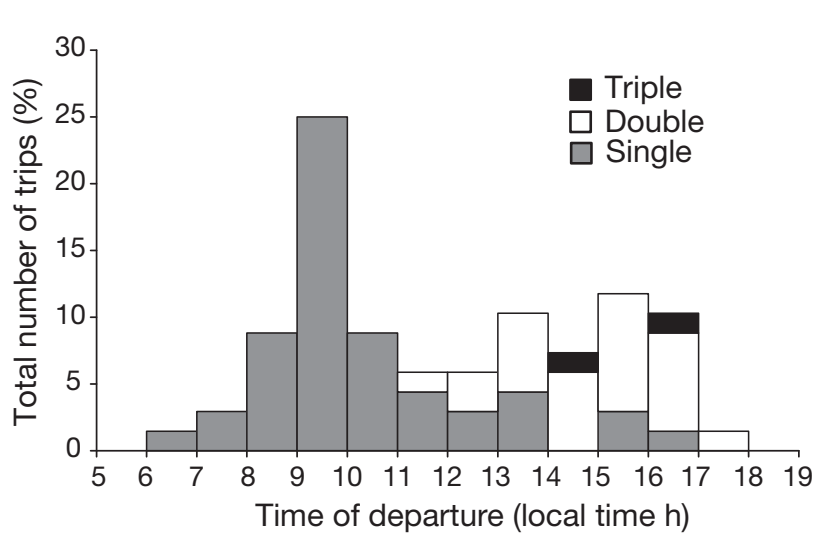

Fig. 2. Sula variegata. Frequency distribution of departure time categorized by the number of trips that individual birds undertook in a day. Data from Isla Lobos de Tierra in December 2006 and Isla Lobos de Afuera in December 2007 were pooled $(\mathrm{N}=43$ trips $)$

from LT than LA (Table 1). Females spent more time at sea than males at LT, but not at LA; however, the difference between sexes and the interaction term were not significant (Table 1).

\section{Diving behavior}

Overall, 88\% ( $\mathrm{N}=1462)$ of the immersions occurred at depths $<4 \mathrm{~m}$ and lasted $<6 \mathrm{~s}$, with median depth and duration of $2.5 \mathrm{~m}(\max =8.81 \mathrm{~m})$ and $4 \mathrm{~s}(\max =19.7 \mathrm{~s})$, respectively. Dive duration increased significantly with dive depth (regression, $F_{1,1424}=1268$, $p<0.001$ ), but the slope of the regression differed between sexes $\left(F_{1,1424}=16.39, \mathrm{p}<0.001\right)$, indicating that the durations of dives increased with depth at a faster rate in males than females until $\sim 2.4 \mathrm{~m}$, where the trend reversed (males: $y=0.41 \ln (x)+1.06, \mathrm{r}^{2}=0.44$; females: $y=0.50$ $\left.\ln (x)+0.98 ; r^{2}=0.51\right)$. Although the difference in mean dive depth between sexes was not statistically significant ( $p=0.06$; Table 1 ), an examination of the divedepth distribution showed that females attained deeper depths than males (>5.5 m only attained by females; Fig. 3). Based on this pattern, the maximum dive depth attained by each bird was compared between sexes. The test to detect differences in maximum dive depths (mixed model test) confirmed that females attained deeper depths than males (Table 1). The same rationale was applied for comparisons of dive depths between islands because the level of significance approached significance $(p=0.08)$, and results showed that the maximum dive depth of birds from LT was significantly greater than birds from LA (Table 1).

Two types of immersions were recognized from the dive profiles: V-shaped dives, when the bird attained

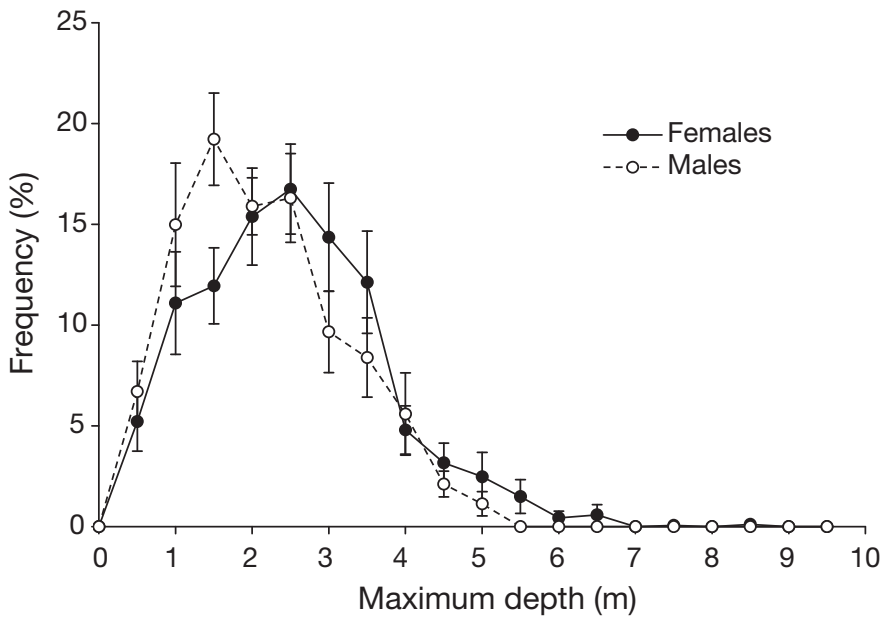

Fig. 3. Sula variegata. Frequency distribution (mean $\pm \mathrm{SE}$ ) of dive depth, averaged per $0.5 \mathrm{~m}$ increment, for females and males $(\mathrm{N}=1462$ dives $)$

the maximum depth returning immediately to the surface, and U-shaped dives, when the bird spent some seconds at the maximum depth before returning to the surface. V-dives were more common (92\% of all dives, $\mathrm{N}=1462$ ) than U-dives. No sex differences in the U/V ratio emerged (Table 1). However, birds from LA performed significantly more U-dives than V-dives compared to birds from LT (Table 1).

The total number of dives in a trip was similar between sexes (Table 1), but birds from LT dived 2.5 times more frequently (median $=43$ dives trip $^{-1}, \mathrm{~N}=18$ trips) than birds from LA (median $=17$ dives trip ${ }^{-1}, \mathrm{~N}=$ 36 ; Table 1). When the total number of dives in a feeding trip was divided by the duration of the trip, the number of dives per hour was similar between islands and between sexes $\left(\right.$ median $=13$ dives $\mathrm{h}^{-1}, \mathrm{~N}=54$; Table 1). Likewise, the number of dives per hour estimated from the time interval between the first and the last plunge in a trip was similar between sexes and islands $\left(\right.$ median $=29.4$ dives $\mathrm{h}^{-1}, \mathrm{~N}=54$; Table 1$)$.

\section{At-sea activities}

Peruvian boobies spent a high proportion of time flying $(92 \%, N=50$ trips) during foraging trips. Sitting on the sea surface was rare (6\% of the time), and time spent diving represented only $2 \%$ of the total trip duration. Birds from LT spent a significantly larger proportion of time sitting on the water and, consequently, a smaller proportion of time flying than birds from LA (Table 1). The percentage of time sitting on the water was similar between sexes (Table 1), but at LT, females spent almost twice the amount of time resting on the sea surface than males (Table 1). 

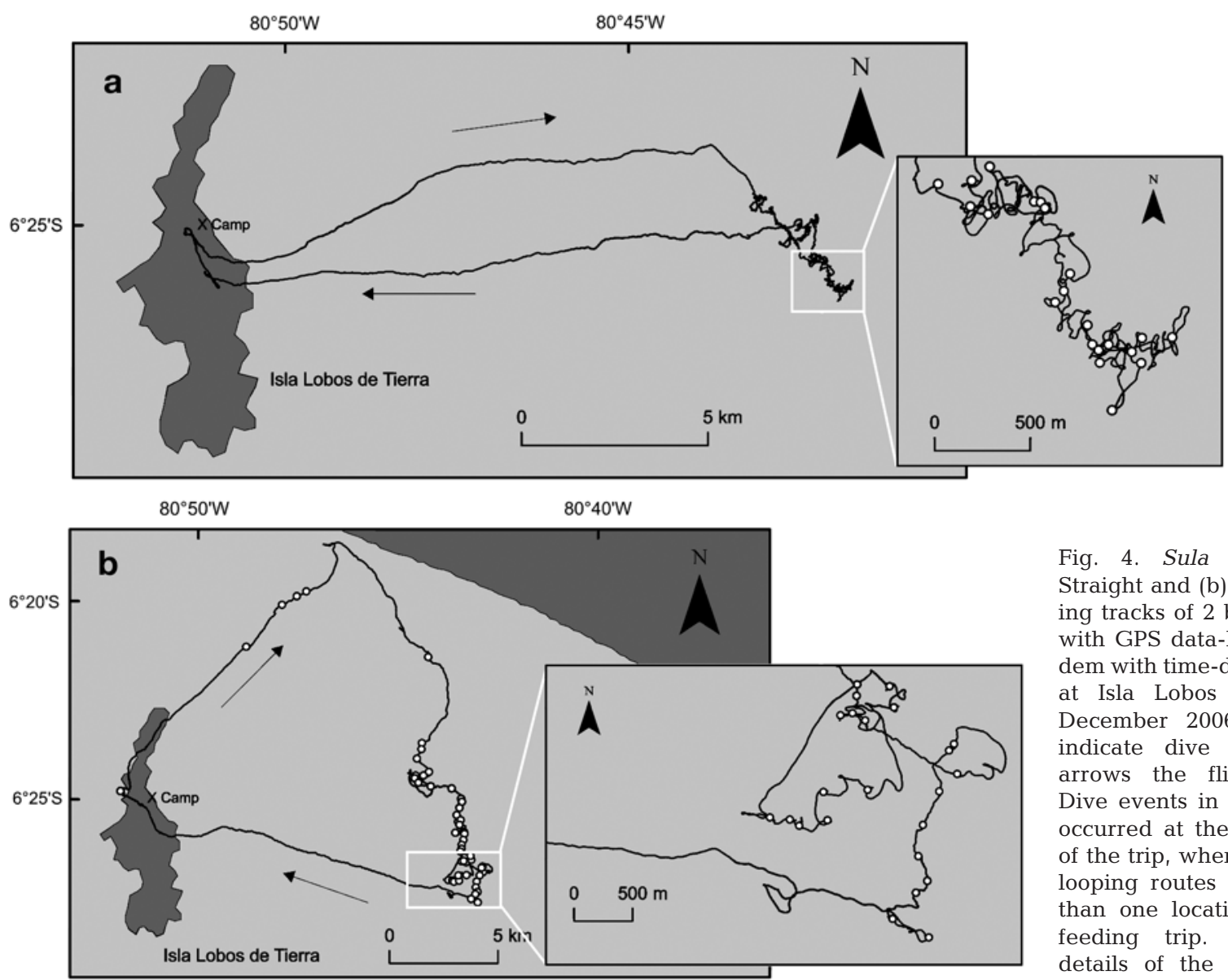

Fig. 4. Sula variegata. (a) Straight and (b) looping foraging tracks of 2 birds equipped with GPS data-loggers in tandem with time-depth recorders at Isla Lobos de Tierra in December 2006. White dots indicate dive locations and arrows the flight direction. Dive events in straight routes occurred at the farthest point of the trip, whereas boobies in looping routes dived at more than one location during the feeding trip. Insets depict details of the path sinuosity

\section{Flight speed and sinuosity of paths}

The average traveling speed ranged from 39 to $46 \mathrm{~km}$ $\mathrm{h}^{-1}$, with bursts between 90 and $139 \mathrm{~km} \mathrm{~h}^{-1}$. There were no sex differences in flight speed, but birds from LA flew significantly faster than birds from LT (Table 1). No significant differences in the sinuosity index between sexes and islands were observed (Table 1). The sinuosity index was significantly lower and less variable during the outward $($ mean $=1.21 \pm 0.20, \mathrm{~N}=50$ birds) and return paths (mean $=1.11 \pm 0.09, \mathrm{~N}=50$ birds) than during the intermediate portion of the foraging trip $($ mean $=2.07 \pm 0.59, \mathrm{~N}=50$ birds; Fig. 4a,b), indicating strong directionality in the travel paths. No multiple interaction effects between sex, island and path section were significant (all $\mathrm{p}>0.09$ ).

\section{Movement patterns}

Foraging tracks of Peruvian boobies were characterized by either straight or looping routes. This categorization was based on the ratio between the maximum foraging distance and the maximum width of the track perpendicular to the maximum foraging distance line.
This ratio varied between 1 (almost circular track) to 33 (outbound and inbound paths parallel and close to each other), with a bimodal distribution and cut-off value of 3.5. Straight tracks (ratio > 3.5) were more common (69\% of all trips, $\mathrm{N}=71$ ) than loops (ratio < 3.5), with feeding activities usually at the farthest end point of the route (Fig. 4a). Birds fed on more than one occasion throughout the trip in looping tracks (Fig. 4b).

Individuals tended to fly in the same direction in consecutive trips both at LT (Watson-Williams test, $F_{1,12}=$ $0.018, \mathrm{p}=0.89)$ and at LA $\left(F_{1,38}=0.601, \mathrm{p}=0.443\right)$, with a bearing difference of $<45^{\circ}$ between 2 consecutive trips in $43 \%$ ( $\mathrm{N}=7$ birds) and $63 \%(\mathrm{~N}=19$ birds $)$ of cases at LT and LA, respectively. Within-day comparisons of flight orientation during 6 consecutive days on LA showed that the angular dispersion of the birds' flight direction was low (mean directional vector $\mathbf{r}>$ 0.79 for all days) and not significantly different among days (Kruskal-Wallis test, $\chi^{2}=2.41$, $\mathrm{df}=5, \mathrm{p}=0.49$ ), i.e. boobies tended to fly in the same direction in a single day when they departed at similar times (within $1 \mathrm{~h}$ from the departure of the first bird, Fig. 5).

Trips from LT were dispersed in a wide arc from the northwest and southeast of the island (mean vector $\mathbf{r}=$ 0.543, $99 \% \mathrm{CI}=20$ to $113^{\circ}$; Fig. 6 ). Birds from LA pref- 

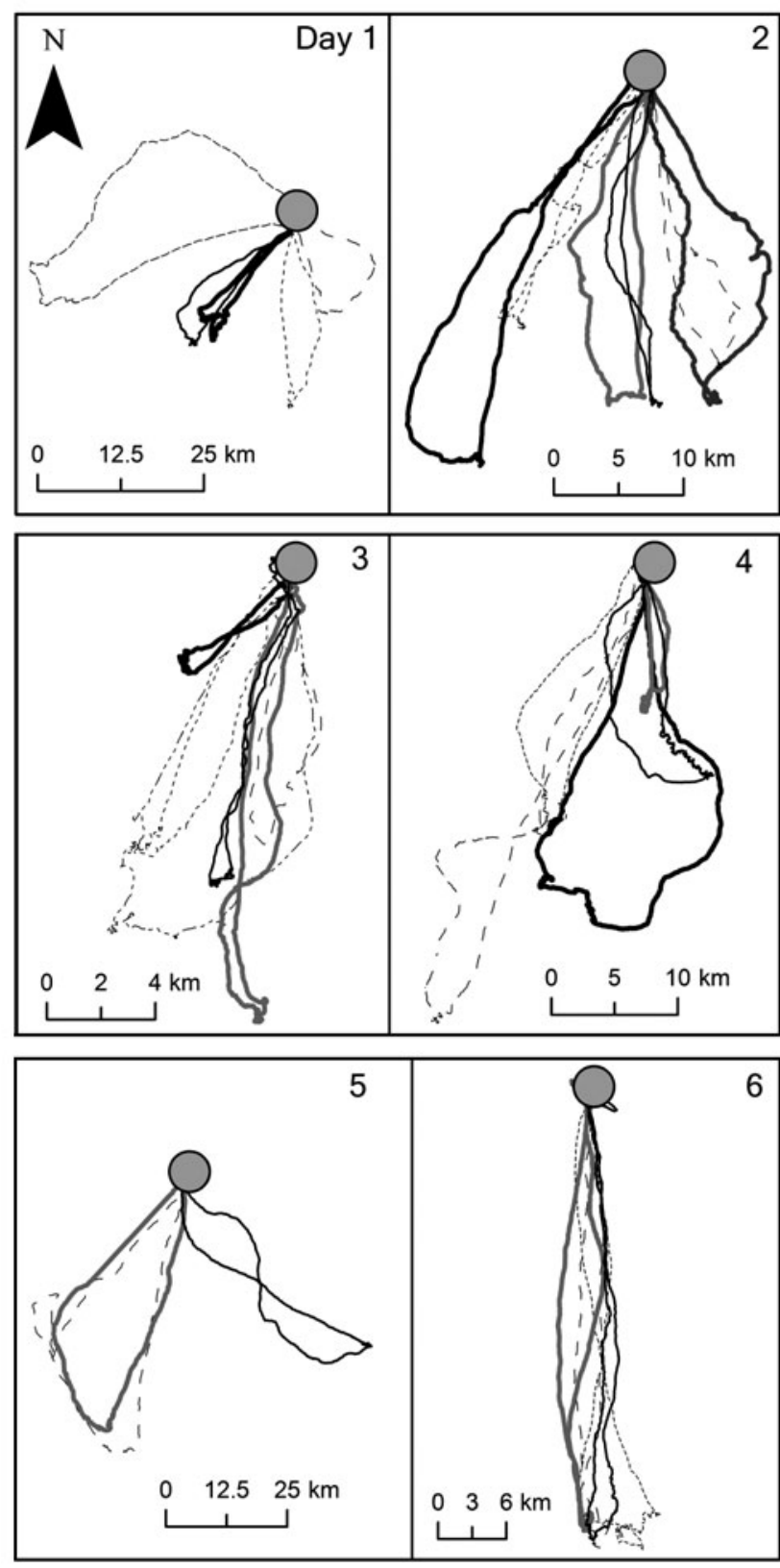

Fig. 5. Sula variegata. Daily variation in the orientation of GPS tracks from Isla Lobos de Afuera recorded during 6 consecutive days (Day 1 = 10 December 2007). Different birds (both females and males) are represented by different line patterns. The island location is symbolized by a grey circle. All birds departed within an interval of $1 \mathrm{~h}$

erentially travelled to the south and southwest of the island (Fig. 6), but in contrast to LT the heading of tracks was more concentrated to a specific location (mean vector $\mathbf{r}=0.824$ ) and had a smaller angular variance $\left(99 \% \mathrm{CI}=176\right.$ to $\left.201^{\circ}\right)$. The mean foraging direction of females and males was similar at LT (Watson's test, $\left.U^{2}=0.097,0.5>\mathrm{p}>0.2\right)$ and LA $\left(U^{2}=0.099,0.5>\right.$ p > 0.2; Fig. 6).
The maximum and total distances traveled in the foraging path were similar between sexes (Table 1). Birds approached the mainland ( $<1 \mathrm{~km}$ from the coastline) in $78 \%$ of the trips on LT ( $\mathrm{N}=18)$, often flying parallel to the shoreline for several kilometers (Fig. 6). Boobies from LA never approached the mainland (the shortest distance to the mainland was $68 \mathrm{~km}$ ). Birds from LT covered significantly longer distances (median = $106 \mathrm{~km}, \mathrm{~N}=18$ trips) than birds from LA (median = $63 \mathrm{~km}, \mathrm{~N}=53$ trips; Table 1). Since there were no significant differences in the maximum foraging range between birds from LT (median $=31 \mathrm{~km}, \mathrm{~N}=18$ ) and birds from LA $($ median $=21 \mathrm{~km}, \mathrm{~N}=53$ trips; Table 1$)$, the differences in the cumulative distance traveled between islands is explained by the exploratory behavior of boobies from LT along the mainland coastline.

Summarizing all foraging data, foraging trip duration increased significantly with maximum foraging distance (regression, $F_{1,24}=57.9, \mathrm{p}<0.001$ ), but the relation differed between islands in the slope of the regressions (ANCOVA, $F_{1,24}=12.34, p=0.002$ ). Trip length of boobies from LA increased with maximum foraging distance at a faster rate than birds from LT (LA: $y=0.055 x+0.29, \mathrm{r}^{2}=0.86, \mathrm{p}<0.001$; LT: $y=$ $\left.0.024 x+2.10, \mathrm{r}^{2}=0.15, \mathrm{p}=0.11\right)$. The coefficients of determination of both equations indicate that trip

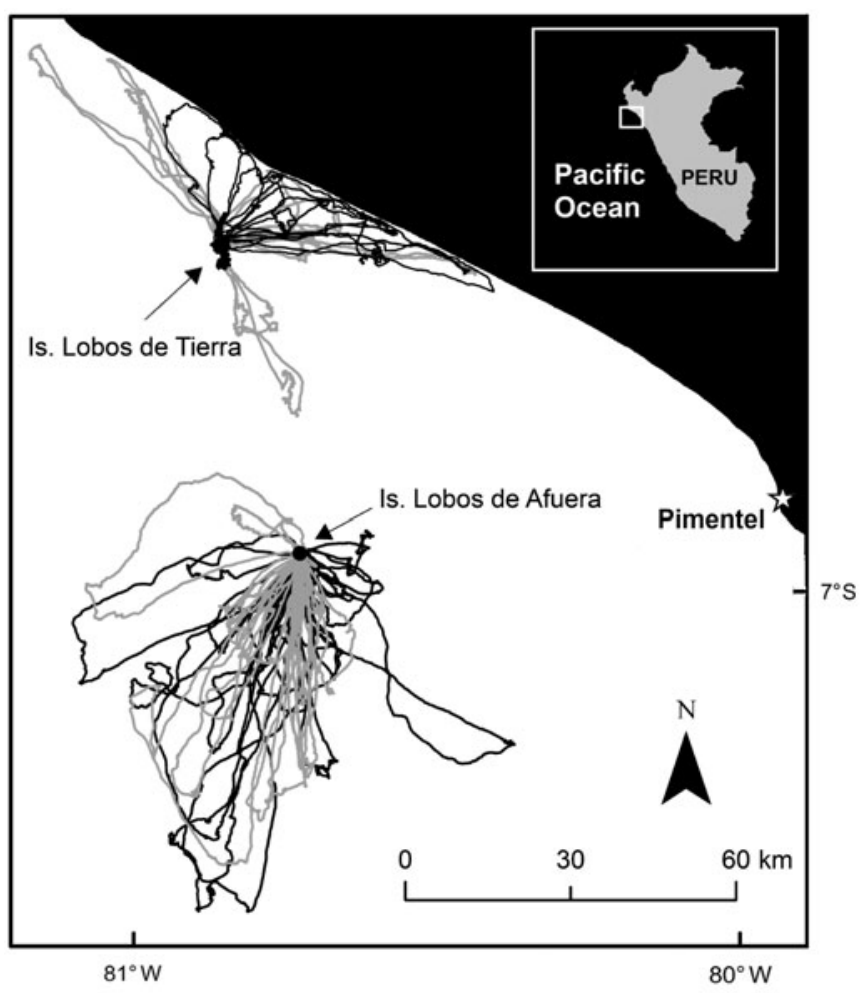

Fig. 6. Sula variegata. Foraging tracks of females (black tracks) and males (grey tracks) at Isla Lobos de Tierra in December 2006 and Isla Lobos de Afuera in December 2007 


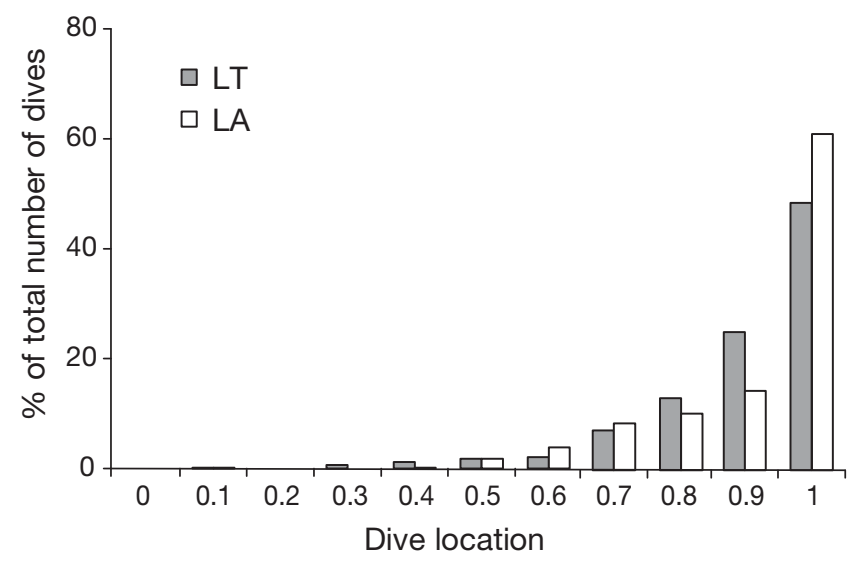

Fig. 7. Sula variegata. Frequency distribution (\% of the total number of dives) of standardized location of dives in relation to the farthest point in the foraging trip at Isla Lobos de Tierra (LT) in December 2006 and Isla Lobos de Afuera (LA) in December 2007. A value close to 1 indicates that dives occurred close to the maximum foraging distance, whereas a value close to 0 indicates that dive locations were close to the island

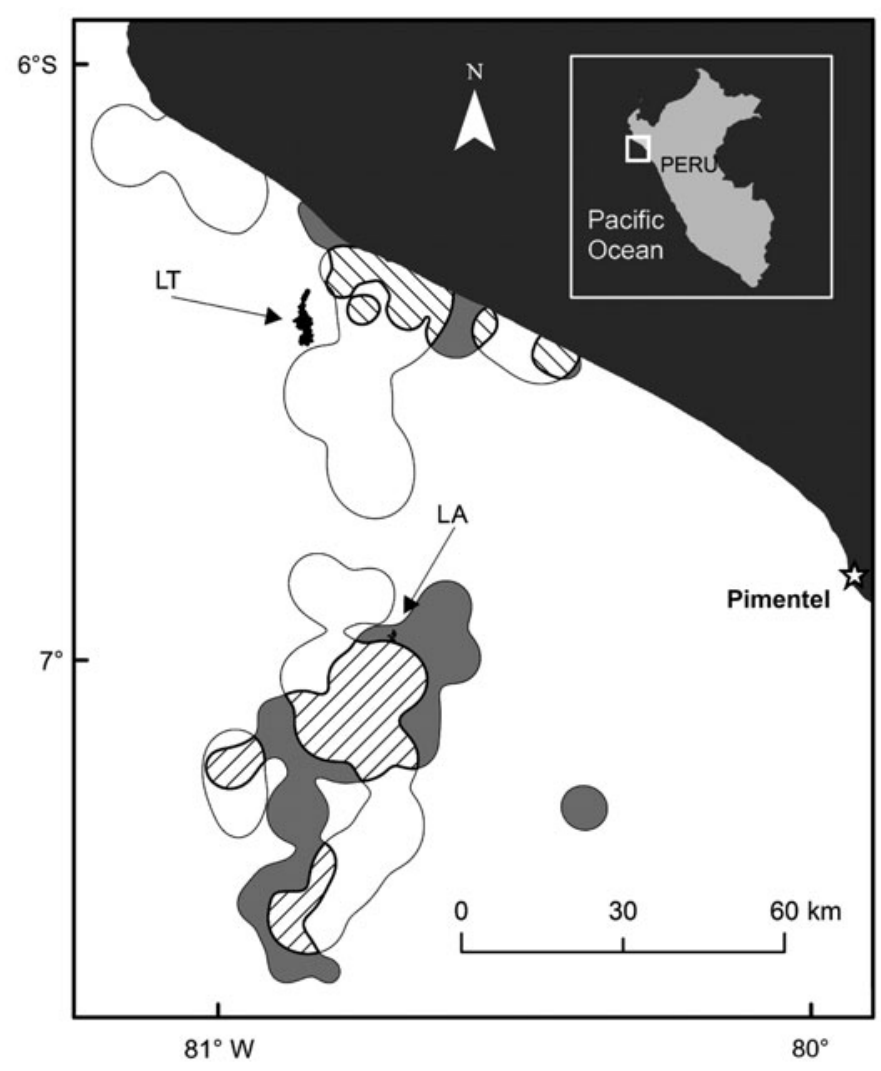

Fig. 8. Sula variegata. Density contour probability polygons $(95 \%)$ from kernel estimates of the pooled dive position fixes of female (grey) and male (white) Peruvian boobies at Isla Lobos de Tierra (LT) in December 2006 and Isla Lobos de Afuera (LA) in December 2007. Polygons where females and males overlapped are indicated by diagonal lines length was a good predictor of maximum foraging distance only at LA.

\section{Foraging areas}

Dives were not evenly distributed along the foraging path (pooled data, K-S test, $D=0.88$, p $<0.001$ ), but were clustered close to the farthest point in the route, with 50 to $60 \%$ of dives $(\mathrm{N}=1343)$ concentrated at a distance equivalent to $<10 \%$ of the maximum distance travelled (Fig. 7).

The mean distance of dive locations in relation to the colony was not significantly different between islands or between sexes (median $=21.3 \mathrm{~km}, \mathrm{~N}=1343$ fixes; Table 1). Females from LT dived significantly closer to the mainland shoreline $($ median $=1.66 \mathrm{~km}$, range $=$ 0.27 to $10.93, \mathrm{~N}=708$ fixes) than males (median $=$ $8.91 \mathrm{~km}$, range $=0.91$ to $38.87 \mathrm{~km}, \mathrm{~N}=735$; K-S test, $D=0.51, \mathrm{p}<0.0001$ ), with approximately 25 and $55 \%$ of the total number of female dives located $<1$ and $<2 \mathrm{~km}$ from the shore, respectively. Dives of females from LT were enclosed in an area of $392 \mathrm{~km}^{2}$, whereas the area visited by males covered $1456 \mathrm{~km}^{2}$. The foraging area of males and females on LT overlapped, with $74 \%$ of the female's area intersected by the male's area, and $20 \%$ of the male's area overlapped by the female's area (Fig. 8). The extent of foraging areas of females $\left(1401 \mathrm{~km}^{2}\right)$ and males $\left(1398 \mathrm{~km}^{2}\right)$ from LA were very similar, with $45 \%$ of the female's area overlapped by the male's area, and $45 \%$ of the male's area included within the female's area (Fig. 8).

\section{Diet}

A total of 5 and 19 regurgitations were recovered on LT and LA, respectively. At both islands, birds fed exclusively on anchoveta. There were no significant differences in the number of fish per regurgitation between females (median $=6$, range $=1$ to $13, N=13$ ) and males (median $=5$, range $=1$ to $12, \mathrm{~N}=11$; MannWhitney $U$-test, $\chi^{2}=0.42, \mathrm{df}=1, \mathrm{p}=0.51$ ).

\section{DISCUSSION}

There were major colony-specific differences in Peruvian booby foraging behavior. Birds from LT approached the mainland coast, spent more time at sea, sat on the water surface for longer periods and dived slightly deeper than birds from LA. Likewise, trip length was not a good predictor of maximum foraging distance on LT because birds spent a considerable amount of time exploring waters along the coast- 
line. Coastal feeding has also been observed in Peruvian boobies from Isla Pajaros (<25 km offshore) in northern central Chile (Ludynia et al. 2009). However, birds from the offshore island of LA never approached the mainland coast, indicating that breeding Peruvian boobies are not exclusively inshore feeders. Furthermore, there was a clear non-overlapping foraging zone between birds from both colonies despite the interisland distance being only $65 \mathrm{~km}$, well within the potential foraging range of either island (Fig. 6). This observation suggests ecological segregation between the 2 neighboring Peruvian booby colonies, maybe to mitigate competition for food (e.g. Cairns 1989); however, this hypothesis requires further investigation because Peruvian boobies from LT and LA were tracked in different seasons and, therefore, the effects of site and year could not be clearly separated. Regardless of this confounding effect, some evidence suggests that Peruvian boobies must exhibit a flexible foraging behavior to cope with the strong interannual variation in oceanographic conditions of the coastal upwelling system off Peru (Bakun \& Weeks 2008). For example, the present study has revealed that Peruvian boobies preferentially foraged to the east of LT, but in other years, these birds also exploited waters to the south of this island (Duffy 1987). Likewise, temporal variations in Peruvian booby diet composition have been attributed to seasonal and interannual changes in prey availability and environmental conditions (Jahncke \& Goya 1998). Sympatric blue-footed boobies that also fed on anchoveta traveled farther from LT and covered a broader area during the winter than during the summer as a result of changes in upwelling intensity (Zavalaga et al. 2008). Thus it is likely that under conditions of low food supply, birds from inshore islands can potentially exploit offshore waters (and vice versa) following anchoveta schools or other pelagic prey. It is important to mention that LT and LA are islands located to the northern limit of the species' distribution range, where the guano bird population size (boobies, cormorants and pelicans) has been historically smaller and anchoveta landings lower than in areas of central Peru (8 to $13^{\circ}{ }^{\circ}$; Jordán 1967, Niquen \& Bouchon 1995). The foraging behavior of Peruvian boobies from southern colonies may differ from that in the north as a result of higher levels of intra- and interspecific competition and more intense fishing activities.

\section{Foraging behavior of Peruvian boobies in comparison to other sulids}

Chick-rearing Peruvian boobies from LT and LA performed multiple short trips per day, spent a low proportion of time sitting on the water, dived at relatively high rates, foraged close to their colonies and returned to the same foraging areas in consecutive trips. High diving rates, short feeding trips and small foraging ranges have also been observed in Peruvian boobies from northern central Chile (Ludynia et al. 2009), bluefooted boobies from Peru (Zavalaga et al. 2007, 2008) and blue-footed and brown boobies that exploit winddriven coastal upwelling waters of Baja California (Weimerskirch et al. 2009). In contrast, tropical boobies dive less extensively, spend more time at sea, exhibit lower foraging site fidelity and travel greater distances than boobies from upwelling areas. For instance, the diving rate of Peruvian boobies was 3 to 5 times higher than that of breeding brown and red-footed boobies from the central tropical Pacific (Lewis et al. 2004), whereas the maximum distance traveled to the foraging areas ranged from $114 \mathrm{~km}$ in red-footed boobies from the Indian Ocean (Weimerskirch et al. 2005b) to $242 \mathrm{~km}$ in masked boobies from the eastern tropical Pacific (Weimerskirch et al. 2008). Masked boobies never returned to the same feeding areas in consecutive trips (Weimerskirch et al. 2008). These marked differences in behavior can be interpreted by the patterns and dynamics of the environmental conditions and intensity of marine productivity between the poor oceanic waters of the tropics and the enriched waters of coastal upwelling areas. In addition, northern gannets dive less frequently (mean dive rate $=1.5$ dives $\mathrm{h}^{-1}$; Lewis et al. 2002), make longer trips (mean $=22 \mathrm{~h}$; Lewis et al. 2002) and travel longer distances (maximum foraging distance $=540 \mathrm{~km}$; Hamer et al. 2000) than Peruvian boobies. But in contrast to tropical boobies, northern gannets return to the same feeding areas in consecutive trips (Hamer et al. 2007), showing that although prey are distant from gannet colonies, they are more spatially predictable at meso- or larger scales (100 to $1000 \mathrm{~km}$ ). Paradoxically, although the primary productivity of the Benguela Current is higher (2500 to $3000 \mathrm{mg} \mathrm{C} \mathrm{m}^{-2} \mathrm{~d}^{-1}$ ) than that of the Humboldt Current ( 2100 mg C m${ }^{-2} \mathrm{~d}^{-1}$, Chavez et al. 2008), Cape gannets from the Benguela coastal upwelling ecosystem dive less frequently (mean dive rate $=3$ to 7.76 dives $\mathrm{h}^{-1}$ ), make longer trips (mean $=8.5$ to $22.6 \mathrm{~h}$ ) and travel longer distances (maximum foraging distance $=242 \mathrm{~km}$ ) than Peruvian boobies (Grémillet et al. 2004). These differences in foraging behavior can be explained in terms of fish density, as the Humboldt Current System off Peru produces more fish per unit area than any other upwelling region in the world's oceans as a result of higher trophic transfer efficiency from primary production to fish (Chavez \& Messié 2009).

The inability of Peruvian boobies to forage at night may be linked to the diurnal activities of sub-surface predators (mainly dolphins) and other diurnal seabirds 
that catalyze the formation of multispecies feeding aggregations (Duffy 1987). Conversely, temperate gannets can spend the night at sea, resting on the water, presumably digesting food during long feeding trips (Garthe et al. 2003, Grémillet et al. 2004). Although tropical boobies can commute during the night, they avoid sitting on the water during periods of darkness, probably to reduce encounters with sharks (Weimerskirch et al. 2008).

In sharp contrast to other sulids, Peruvian boobies from LT and LA usually made multiple trips in a day. The higher frequency of foraging excursions by Peruvian boobies may not only be related to the proximity of food to the breeding areas, but also to the higher energetic demands of the brood in comparison to their relatives. They have the largest brood size (up to 4 chicks) within the Sulidae (Nelson 1978) and, during periods of high food supply, they can breed twice in a year (Murphy 1936, Nelson 1978, C. Zavalaga pers. obs.). This breeding trait contrasts with the low fecundity of most seabirds, particularly with tropical pelagic boobies and temperate gannets (single chick broods), and has probably evolved under the rich environment of the Humboldt Current to compensate for poor reproductive output and high adult mortality during strong ENSO events (Murphy 1936, Nelson 1978). Since enlarged broods and high provisioning rates of some seabird species depend upon conditions of high food supply around seabird colonies (Drent \& Daan 1980, Ryan et al. 2007), we expected more frequent trips in Peruvian boobies than in other sulids. This hypothesis is supported by the fact that bluefooted boobies with 3-chick broods can also make multiple trips in a day on LT (Zavalaga et al. 2007), whereas their counterparts with smaller broods from the Galápagos and Baja California perform single trips (Drummond et al. 1986, Anderson \& Ricklefs 1992, Weimerskirch et al. 2009).

Three Peruvian boobies from northern central Chile instrumented with depth meters attained mean dive depths of 2.3, 2.5 and $4.3 \mathrm{~m}$, respectively ( $\max =10.3 \mathrm{~m}$; Ludynia et al. 2009), records that are comparable to those found in the present study (mean $=2.5 \mathrm{~m}$, $\max =$ $8.8 \mathrm{~m})$. Thus Peruvian boobies dived deeper than brown (mean $=0.8 \mathrm{~m}, \max =3.8 \mathrm{~m}$; Lewis et al. 2005, Yoda \& Kohno 2008) and red-footed boobies (mean = $0.87 \mathrm{~m}, \max =2.4 \mathrm{~m}$; Weimerskirch et al. 2005a,b, Lewis et al. 2005), and attained depths similar to masked boobies $($ mean $=2.2 \mathrm{~m}$, $\max =5 \mathrm{~m}$; Weimerskirch et al. 2008). Although Peruvian boobies are heavier (1200 to $1675 \mathrm{~g}$ ) than brown (850 to $1550 \mathrm{~g}$; Nelson 1978) and red-footed boobies (800 to $1210 \mathrm{~g}$; Nelson 1978), their dive capabilities were not necessarily associated with body size because masked boobies are much heavier (1500 to 2350 g; Nelson 1978) than Peru- vian boobies. Rather, interspecific variations in dive depths of Peruvian and tropical boobies seem to reflect the behavior and vertical distribution of prey. Tropical boobies feed mainly on flying fish and squid (Asseid et al. 2006, Weimerskirch et al. 2008), which can be seized in aerial dives or near the sea surface after being chased by sub-surface predators such as tuna and dolphin (Jaquemet et al. 2004). Conversely, Peruvian boobies need to submerge some meters below the surface because anchoveta usually occur in the upper 2 to $30 \mathrm{~m}$ of the water column (Mathisen 1989).

\section{Foraging behavior of Peruvian boobies in comparison to the sympatric blue-footed booby}

Peruvian and blue-footed boobies breed sympatrically on LT and LA, at the limit of their distribution range in northern Peru (Duffy 1987). In this overlapping area, the peak of the chick-rearing period of both species occurs during the austral summer (December-March). Initially, blue-footed and Peruvian boobies were considered ecological replacements of one another, with Peruvian boobies confined to the cold waters of the Humboldt Current and blue-footed boobies associated with the warm tropical waters of northern Peru (Nelson 1978, Duffy 1987). Nevertheless, new evidence has shown that blue-footed boobies also forage within the boundaries of the Peruvian coastal upwelling system and that both species exploit the same feeding zones around LT in search of anchoveta during cold years (Zavalaga et al. 2008, present study). Overlapping of foraging areas is not only extensive, but both booby species also coincide in the timing of foraging, number of trips in a day, foraging duration, diet composition and time allocation of at-sea activities (Zavalaga et al. 2007, 2008). These similarities in foraging behavior suggest that interspecific competition for anchoveta might be intense, but it is also likely that, during conditions of high food supply, both species coexist, and that competition would emerge under poor conditions. For example, when anchoveta availability considerably decreased around LT during the strong 1997-1998 ENSO, bluefooted boobies switched to consume coastal fish, whereas Peruvian boobies deserted the island (Jahncke \& Goya 2000). It is also possible that both species mitigate competition as a result of differences in diving behavior. Blue-footed boobies dive deeper (mean = $4.4 \mathrm{~m}, \max =22 \mathrm{~m})$, longer $($ mean $=6.55 \mathrm{~s}, \max =39 \mathrm{~s})$ and more frequently $\left(\right.$ mean $=18.3$ dives $\mathrm{h}^{-1}, \max =$ 50.8 dives $\mathrm{h}^{-1}$ ) than Peruvian boobies (Zavalaga et al. 2007, Ludynia et al. 2009, present study), which suggests a possible feeding niche partitioning below the sea surface. 


\section{Sex-specific foraging behavior}

There is an extensive list of evidence demonstrating that sex differences in body size and morphology are responsible for foraging habitat segregation in several vertebrate taxa (reviewed in Ruckstuhl \& Neuhaus 2005). In seabirds, sexual size dimorphism leads to competitive exclusion in feeding territories (GonzálezSolís et al. 2000), differential use of feeding habitats (Shaffer et al. 2001, Phillips et al. 2004) or partitioning of parental roles (Gilardi 1992, Clarke 2001, Weimerskirch et al. 2009). Some monomorphic seabird species also forage at different locations, dive at different depths and spent different amounts of time on the sea surface (Lewis et al. 2002, Peck \& Congdon 2006), indicating that body size is not exclusively associated with habitat segregation. Local environmental conditions, interactions with conspecifics and other species, prey behavior and distribution, sex-specific energetic demands of breeding adults and stage of the breeding cycle (e.g. incubating versus chick rearing birds) may also alter the magnitude and direction of habitat segregation between sexes (e.g. Lewis et al. 2002, Weimerskirch et al. 2005a, 2009).

The results of the present study demonstrate that there was no sex-specific spatial segregation of foraging in Peruvian boobies. Although females from LT foraged in coastal waters to the east $(<11 \mathrm{~km}$ from the mainland), whereas males fed farther offshore $(<38 \mathrm{~km}$ from the mainland) without a specific directionality, the small number of tracked birds $(7$ males versus 4 females) on this island may cause false rejection of the null hypothesis (Type I error), particularly because the preference to visit offshore waters was only recorded in 2 males. When the sample size was substantially increased at LA (15 males, 19 females), no spatial segregation was observed. Additionally, there were no sex-specific differences in flight speed, foraging duration, sinuosity of the flight path or at-sea time allocation. These results contrast with those found in other sulids with different levels of size dimorphism (e.g. Cape gannets and brown, blue-footed and red-footed boobies), where females usually make longer trips, cover more distance and fly at higher speeds (Grémillet et al. 2004, Weimerskirch et al. 2006, 2009, Mullers \& Navarro 2009). Some of these foraging parameters are directly related to body size in some species of boobies (Weimerskirch et al. 2009), and therefore it was expected that sex-specific differences in foraging behavior of Peruvian boobies would exist because females are $19 \%$ heavier and 3 to $4 \%$ larger than males. However, the absence of clear foraging niche segregation between sexes may have been the result of prey abundance close to Peruvian booby colonies during the study period as evidenced by short trips, presence of relatively cold waters around the islands, occurrence of anchoveta in the diet and large brood size of studied birds. The highly productive waters of the Humboldt Current catalyze the association of multispecies aggregations (seabirds and sub-surface predators) in conspicuous feeding frenzies within sight of Peruvian booby colonies and nearby areas (Duffy 1983a, Zavalaga et al. 2007); consequently, both sexes may be attracted to these feeding flocks when commuting to foraging areas. The predictability and frequency of these aggregations contrast with that of tropical waters, where patches of prey availability for seabirds are rare and unpredictable (Anderson \& Ricklefs 1987, Ballance et al. 1997, Mills 1998, Jaquemet et al. 2004). Duffy (1983a) found that $99 \%$ of the 28 species of seabirds feeding in the Humboldt Current foraged in flocks and these large groups persisted for 2 to $3 \mathrm{~h}$ or more when feeding on anchoveta. The seabird feeding flocks in Peru can only be supported by huge shoals of anchoveta that usually occur in patches (Jordán 1971, Mathisen 1989, Ganoza et al. 2000).

Female Peruvian boobies dived slightly deeper and spent a larger proportion of the foraging time sitting on the water. Although the 2 sexes foraged in the same areas and at the same time of day, ecological differentiation between sexes may occur underwater, once the anchoveta schools have been detected. Male and female sulids plunge dive over the shoal, using the momentum of the fall to gain depth (Ropert-Coudert et al. 2004), with females diving deeper than males as a consequence of their heavier weight (Weimerskirch et al. 2006, 2009, Zavalaga et al. 2007). After feeding, Peruvian booby females rested for a longer time on the sea surface, presumably because the cost of obtaining flight after diving may be higher in larger individuals (Weimerskirch et al. 2000, Lewis et al. 2005). The idea that biomechanic constraints explain sex-specific differences in dive depth of Peruvian boobies is corroborated by observations on diving behavior of bluefooted boobies (females are $31 \%$ heavier and 6 to $9 \%$ larger than males, and are thus 2 times more dimorphic than Peruvian boobies) that breed on LT (Zavalaga et al. 2007). The difference in dive depth between female and male blue-footed boobies is twice that observed in Peruvian boobies (Zavalaga et al. 2007, present study), in accordance with the hypothesis that the extent in the differences of foraging behavior between females and males of 2 sympatric species would differ in proportion to sexual dimorphism (Lewis et al. 2005).

\section{CONCLUSIONS}

The foraging behavior of Peruvian boobies substantially differs from that of their tropical and temperate 
relatives. Interspecific comparisons of foraging strategies suggest that these differences are explained not only by the higher productivity of the marine environment that these birds exploit during the breeding season, but also by the greater levels of fish per unit area of the Humboldt Current System in comparison to other oceans. Energy constraints of the large brood of Peruvian boobies, in comparison to other members of the Sulidae, may obligate the parents to make multiple short trips in a day to fulfill the energetic demands of the chicks. The small number of instrumented birds in the present study precluded a reliable analysis of the effect of brood size on foraging behavior, but further studies must incorporate this variable to test this hypothesis. The superabundance of food around Peruvian booby colonies may also explain the lack of sexspecific differences in the majority of foraging variables, because females and males are attracted to conspicuous and long-lasting multispecies feeding aggregations that can only be supported by huge schools of anchoveta. Females dived slightly deeper than males, probably as a result of biomechanic constraints, but diving behavior should be assessed under different environmental conditions to corroborate this difference. If food competition is the driving force for disruptive selection of the sexes, then it is expected that intersexual feeding-niche segregation of Peruvian boobies would occur during ENSO years when anchoveta are deeper and more dispersed (Arntz \& Fahrbach 1996). Likewise, tracking of incubating adults in future studies is necessary to complement the results from chick-rearing birds, because the foraging behavior of seabirds may differ at different stages of the breeding cycle (Phillips et al. 2004, Weimerskirch et al. 2005a). Preliminary results here from LT in December 2006 suggest that sexual segregation may emerge under poor food conditions, a hypothesis worthy of additional investigation.

Acknowledgements. We are grateful to all of those who participated in this study, particularly to M. Müller, who traveled with us to the islands. We thank the island wardens R. Balbín and A. Nieto for their hospitality and for making life much easier on the guano islands, as well as local fishermen on Lobos de Tierra who provided car batteries to recharge our data-loggers. We thank National Geographic for travel funding and PROABONOS (permits 172-2006-AG-PROABONOS/ DE and 186-2007-AG-PROABONOS-GO/DE) and INRENA (permits 120-2006-INRENA-IFFS-DCB and 011352-AGINRENA), who gave us permission to work on the islands. We also thank S. Emslie, D. Anderson and 5 anonymous reviewers for editorial advice.

\section{LITERATURE CITED}

Adams NJ, Navarro RA (2005) Foraging of a coastal seabird: flight patterns and movements of breeding Cape gannets Morus capensis. Afr J Mar Sci 27:239-248
Anderson DJ, Ricklefs RE (1987) Radio-tracking masked and blue-footed boobies (Sula spp.) in the Galápagos Islands. Natl Geogr Res 3:152-163

Anderson DJ, Ricklefs RE (1992) Brood size and chick provisioning in masked and blue-footed boobies (Sula spp.). Ecology 73:1363-1374

Arntz WE, Fahrbach E (1996) El Niño: experimento climático de la naturaleza. Fondo de Cultura Económica, México DF

Asseid BS, Drapeau L, Crawford RJM, Dyer BM and others (2006) The food of three seabirds at Latham Island, Tanzania, with observations on foraging by masked boobies Sula dactylatra. Afr J Mar Sci 28:109-114

Au DWK, Pitman RL (1986) Seabird interactions with dolphins and tunas. Condor 88:304-317

Bakun A (1987) Monthly variability in the ocean habitat off Peru as deduced from maritime observations, 1953 to 1984. In: Pauly D, Tsukayama I (eds) The Peruvian anchoveta and its upwelling ecosystem: three decades of change. ICLARM Studies and Reviews 15. Instituto del Mar del Peru, Callao, p 46-74

Bakun A, Weeks SJ (2008) The marine ecosystem off Peru: What are the secrets of its fishery productivity and what might its future hold? Prog Oceanogr 79:290-299

Ballance LTR, Pitman RL, Reilly SB (1997) Seabird community structure along a productivity gradient: importance of competition and energetic constraint. Ecology 78: 1502-1518

Barber RT, Chavez FP, Kogelschatz JE (1985) Biological effects of El Niño. Bol ERFEN 14:3-29

Batschelet E (1981) Circular statistics in biology. Academic Press, New York

Biuw M, Boehme L, Guinet C, Hindell M, Costa D, and others (2007) Variations in behavior and conditions of a Southern Ocean top predator in relation to in situ oceanographic conditions. Proc Natl Acad Sci USA 104:13705-13710

Cairns DK (1989) Regulation of seabird colony size: the hinterland model. Am Nat 134:141-146

Camphuysen CJ, Scott BE, Wanless S (2006) Distribution and foraging interactions of seabirds and marine mammals in the North Sea: multispecies foraging assemblages and habitat-specific feeding strategies. In: Boyd I, Wanless S, Camphuysen CJ (eds) Top predators in marine ecosystems: their role in monitoring and management. Cambridge University Press, Cambridge, p 82-97

Catry P, Phillips RA, Furness RW (1999) Evolution of reversed sexual size dimorphism in skuas and jaegers. Auk 116: $158-168$

Chavez FP, Messié M (2009) A comparison of eastern boundary upwelling ecosystems. Prog Oceanogr 83:80-96

> Chavez FP, Bertrand A, Guevara-Carrasco R, Soler P, Csirke J (2008) The northern Humboldt Current System: brief history, present status and a view towards the future. Prog Oceanogr 79:95-105

> Clarke JR (2001) Partitioning of foraging effort in Adélie penguins provisioning chicks at Béchervaise Island, Antarctica. Polar Biol 24:16-20

Crawford RJM, Goya E, Rouz JP, Zavalaga CB (2006) Comparison of assemblages and some life-history traits of seabirds in the Humboldt and Benguela systems. Afr J Mar Sci 28:553-560

> Daneri G, Dellarossa V, Quiñones R, Jacob B, Montero P, Ulloa O (2000) Primary production and community respiration in the Humboldt Current System off Chile and associated oceanic areas. Mar Ecol Prog Ser 197:41-49

Daunt F, Wanless S, Peters G, Benvenuti S, Sharples J, Grémillet D, Scott B (2006) Impacts of oceanography on the foraging dynamics of seabirds in the North Sea. In: 
Boyd I, Wanless S, Camphuysen CJ (eds) Top predators in marine ecosystems: their role in monitoring and management. Cambridge University Press, Cambridge, p 177-190

Drent RH, Daan S (1980) The prudent parent: energetic adjustments in avian breeding. Ardea 68:225-252

> Drummond H, Gonzalez E, Osorno JL (1986) Parent-offspring cooperation in the blue-footed booby (Sula nebouxii): social roles in infanticide brood reduction. Behav Ecol Sociobiol 19:365-372

Duffy DC (1983a) The foraging ecology of Peruvian seabirds. Auk 100:800-810

- Duffy DC (1983b) Environmental uncertainty and commercial fishing: effects on Peruvian guano birds. Biol Conserv 26: 227-238

Duffy DC (1987) Aspects of the ecology of blue-footed and Peruvian boobies at the limits of their ranges on Isla Lobos de Tierra, Perú. Colon Waterbirds 10:45-49

Figueroa J, Stucchi M (2008) Las aves de la Isla Lobos de Afuera (Peru) en la primavera del 2008. Ornitol Neotrop 19:377-390

Ganoza F, Castillo PR, Marín D (2000) Variaciones estacionales en la distribución y biomasa de anchoveta entre 1983 y 2000. Bol Inst Mar Peru 19:157-177

Garthe S, Benvenuti S, Montevecchi W (2003) Temporal patterns of foraging activities of northern gannets, Morus bassanus, in the northwest Atlantic Ocean. Can J Zool 81: 453-461

Gende SM, Sigler MF (2006) Persistence of forage fish 'hot spots' and its association with foraging Steller sea lions (Eumetopias jubatus) in southeast Alaska. Deep-Sea Res II 53:432-441

Gilardi JD (1992) Sex-specific foraging distributions of brown boobies in the Eastern Tropical Pacific. Colon Waterbirds 15:148-151

González-Solís J, Croxall JP, Wood AG (2000) Sexual dimorphism and sexual segregation in foraging strategies of northern giant petrels, Macronectes halli, during incubation. Oikos 90:390-398

Goya E (2000) Abundancia de aves guaneras y su relación con la pesquería de anchoveta peruana 1953 a 1999. Bol Inst Mar Peru 19:125-131

Grémillet D, Dell'Omo G, Ryan PG, Peters G, Ropert-Coudert Y, Weeks SJ (2004) Offshore diplomacy, or how seabirds mitigate intra-specific competition: a case study on GPS tracking of Cape gannets from neighbouring colonies. Mar Ecol Prog Ser 268:265-279

- Hamer KC, Phillips RA, Wanless S, Harris MP, Wood AG (2000) Foraging ranges, diets and feeding locations of gannets Morus bassanus in the North Sea: evidence from satellite telemetry. Mar Ecol Prog Ser 200:257-264

Hamer KC, Phillips RA, Hill JA, Wanless S, Wood AG (2001) Contrasting foraging strategies of gannets Morus bassanus at two North Atlantic colonies: foraging trip duration and foraging area fidelity. Mar Ecol Prog Ser 224:283-290

Hamer KC, Humphreys EM, Garthe S, Hennicke J and others (2007) Annual variation in diets, feeding locations and foraging behaviour of gannets in the North Sea: flexibility, consistency and constraint. Mar Ecol Prog Ser 338: 295-305

Hooge PN, Eichenlaub B (1997) Animal movement extension to Arcview, version 1.1. US Geological Survey, Anchorage, AK

Hunt GL Jr, Schneider DC (1987) Scale dependent processes in the physical and biological environment of seabirds. In: Croxall JP (ed) Seabirds: feeding ecology and role in marine ecosystems. Cambridge University Press, Cambridge, p $7-41$
Hyrenbach KD, Fernández P, Anderson DJ (2002) Oceanographic habitats of two sympatric North Pacific albatrosses during the breeding season. Mar Ecol Prog Ser 233: 283-301

Jahncke J, Goya E (1998) Las dietas del guanay y piquero peruano como indicadores de la abundancia y distribución de anchoveta. Bol Inst Mar Peru 17:15-34

Jahncke J, Goya E (2000) Responses of three booby species to El Niño 1997-1998. Waterbirds 23:102-108

Jahncke J, Zileri D (1998) Estudios sobre dieta de piqueros como indicadores de la estructura por tallas de los stocks de anchoveta en el mar peruano. Bol Inst Mar Peru 17: $47-54$

Jahncke J, Ayala L, Mendoza C (1998) Abundancia relativa y distribución de aves marinas frente a la costa peruana y su relación con la abundancia de anchoveta. Crucero BIC Humboldt 9808-09, de Piura a Lima. Inf Inst Mar Peru 141:85-95

Jahncke J, Checkley DM, Hunt GL Jr (2004) Trends in carbon flux to seabirds in the upwelling system: effects of wind and fisheries on population regulation. Fish Oceanogr 13: 208-223

> Jaquemet SM, Le Corre M, Weimerskirch H (2004) Seabird community structure in a coastal tropical environment: importance of natural factors and fish aggregating devices (FADs). Mar Ecol Prog Ser 268:281-292

Jordán R (1967) The predation of guano birds on the Peruvian anchovy (Engraulis ringens Jenyns). Calif Coop Ocean Fish Invest Rep 1:105-109

Jordán R (1971) Distribution of anchoveta (Engraulis ringens) in relation to the environment. Invest Pesq (Barcelona) 35:113-126

Lewis S, Benvenuti S, Dall'Antonia L, Griffiths R and others (2002) Sex-specific foraging behavior in a monomorphic seabird. Proc Biol Sci 269:1687-1693

> Lewis S, Schreiber EA, Daunt F, Schenk GA, Wanless S, Hamer KC (2004) Flexible foraging patterns under different time constrains in tropical boobies. Anim Behav 68: 1331-1337

Lewis S, Schreiber EA, Daunt F, Schenk GA and others (2005) Sex-specific foraging behavior in tropical boobies: Does size matter? Ibis 147:408-414

Ludynia K, Garthe S, Luna-Jorquera G (2009) Distribution and foraging behaviour of the Peruvian booby (Sula variegata) off northern Chile. J Ornithol 151:103-111

Mathisen OA (1989) Adaptation of the anchoveta (Engraulis ringens) to the Peruvian upwelling system. In Pauly D, Muck P, Mendo J, Tsukayama I (eds) The Peruvian upwelling ecosystem: dynamics and interactions. ICLARM Conference Proceedings 18, Instituto del Mar Del Perú, Callao, p 438-448

Mills K (1998) Multispecies seabird feeding flocks in the Galápagos Islands. Condor 100:277-285

Mullers RHE, Navarro RA (2009) Foraging trips of breeding Cape gannets: their association with sex, diet, breeding success and colony status. In Mullers RHE (ed) The commuting parent: energetic demands in a long distance forager, the Cape gannet. Van Denderen BV, Groningen, p 75-91

Murphy RC (1936) Oceanic birds of South America. American Museum of Natural History, New York

Nelson JB (1978) The Sulidae: gannets and boobies. Oxford University Press, Oxford

Ñiquen M, Bouchon M (1995) Información estadística de la pesquería pelágica en la costa peruana 1981-1993. Inf Inst Mar Peru 107:1-59

> Pauly D, Christensen V, Guénette S, Pitcher TJ and others 
(2002) Towards sustainability in world fisheries. Nature 418:689-695

Peck DR, Congdon DC (2006) Sex-specific chick provisioning and diving behavior in the wedge-tailed shearwater Puffinus pacificus. J Avian Biol 37:245-251

Phillips RA, Silk JRD, Phalan B, Catry P, Croxall JP (2004) Seasonal sexual segregation in two Thalassarche albatross species: Competitive exclusion, reproductive role specialization or foraging niche divergence? Proc R Soc B 271:1283-1291

Ropert-Coudert Y, Grémillet D, Kato A, Ryan PG, Naito Y, Le Maho Y (2004) A fine-scale time budget of cape gannets provides insights into the foraging strategies of coastal seabirds. Anim Behav 67:985-992

Ruckstuhl KE, Neuhaus P (2005) Sexual segregation in vertebrates: ecology of the two sexes. Cambridge University Press, Cambridge

Ryan PG, Phillips RA, Nel DC, Wood AG (2007) Breeding frequency in grey-headed albatrosses Thalassarche chrysostoma. Ibis 149:45-52

Seaman DE, Powell RA (1996) An evaluation of the accuracy of kernel density estimators for home range analysis. Ecology 77:2075-2085

Serrano-Meneses MA, Székely T (2006) Sexual size dimorphism in seabirds: sexual selection, fecundity selection and differential niche-utilisation. Oikos 113:385-394

Shaffer SA, Weimerskirch H, Costa DP (2001) Functional significance of sexual dimorphism in wandering albatross, Diomedea exulans. Funct Ecol 15:203-210

Tovar H, Guillén V (1988) Comportamiento alimenticio del piquero Sula variegata, ave guanera peruana. Bol Lima 60:85-90

- Weichler T, Garthe S, Luna-Jorquera G, Moraga J (2004) Seabird distribution on the Humboldt Current in northern Chile in relation to hydrography, productivity, and fisheries. ICES J Mar Sci 61:148-154

- Weimerskirch H (2007) Are seabirds foraging for unpredictable resources? Deep-Sea Res II 54:211-223

Weimerskirch H, Guionnet T, Martin J, Shaffer SA, Costa DP (2000) Fast and fuel efficient? Optimal use of wind by flying albatrosses. Proc R Soc Lond B 267:1869-1874

Weimerskirch H, Le Corre M, Ropert-Coudert Y, Kato A, Marsac F (2005a) The three-dimensional flight of redfooted boobies: adaptations to foraging in a tropical environment? Proc R Soc B 272:53-61

Editorial responsibility: Rory Wilson,

Swansea, UK
Weimerskirch H, Le Corre M, Jaquemet S, Marsac F (2005b) Foraging strategy of a tropical seabird, the red-footed booby, in a dynamic marine environment. Mar Ecol Prog Ser 288:251-261

- Weimerskirch H, Le Corre M, Ropert-Coudert Y, Kato A, Marsac F (2006) Sex-specific foraging behaviour in a seabird with reversed sexual dimorphism: the red-footed booby. Oecologia 146:681-691

> Weimerskirch H, Le Corre M, Bost ChA (2008) Foraging strategy of masked boobies from the largest colony in the world: relationship to environmental conditions and fisheries. Mar Ecol Prog Ser 362:291-302

- Weimerskirch H, Shaffer SA, Tremblay Y, Costa DP and others (2009) Species- and sex-specific differences in foraging behaviour and foraging zones in blue-footed and brown boobies in the Gulf of California. Mar Ecol Prog Ser 391:267-278

Welcker J, Steen H, Harding AMA, Gabrielsen GW (2009) Sex-specific provisioning behaviour in a monomorphic seabird with a bimodal foraging strategy. Ibis 151: 502-513

Wood AG, Naef-Daenzer B, Prince PA, Croxall JP (2000) Quantifying habitat use in satellite-tracked pelagic seabirds: application of kernel estimation to albatross locations. J Avian Biol 31:278-286

Yoda K, Kohno H (2008) Plunging behaviour in chick-rearing brown boobies. Ornithol Sci 7:5-13

Zar JH (1999) Biostatistical analysis. Prentice-Hall, Upper Saddle River, NJ

Zavalaga CB, Benvenuti S, Dall'Antonia L, Esmlie SD (2007) Diving behavior of blue-footed boobies Sula nebouxii in northern Peru in relation to sex, body size and prey type. Mar Ecol Prog Ser 336:291-303

Zavalaga CB, Benvenuti S, Dall'Antonia L, Emslie SD (2008) Foraging areas of breeding blue-footed boobies Sula nebouxii in northern Peru, as determined by direction recorders. J Avian Biol 39:405-412

Zavalaga CB, Taylor SA, Dell'Omo G, Anderson DJ, Friesen VL (2009) Male/female classification of the Peruvian booby. Wilson J Ornithol 121:739-744

Zavalaga CB, Halls JN, Dell'Omo G (2010) Marine habitat use of Peruvian boobies: a geographic and oceanographic comparison between inshore and offshore islands. ICES J Mar Sci 67, doi:10.1093/icesjms/fsp298

Submitted: March 2, 2009; Accepted: January 15, 2010

Proofs received from author(s): March 18, 2010 